\title{
Estrogen Regulation of GRK2 Inactivates Kappa Opioid Receptor Signaling Mediating Analgesia, But Not Aversion
}

\author{
Antony D. Abraham, ${ }^{1 \star}$ Selena S. Schattauer, ${ }^{1 \star}$ (OKathryn L. Reichard, ${ }^{2}$ Joshua H. Cohen, ${ }^{1}$ Harrison M. Fontaine, ${ }^{1}$ \\ DAllisa J. Song, ${ }^{1}$ Salina D. Johnson, ${ }^{1}$ Benjamin B. Land, ${ }^{1}$ and ${ }^{\circledR C}$ Charles Chavkin ${ }^{1,2}$ \\ ${ }^{1}$ Department of Pharmacology and ${ }^{2}$ Graduate Program in Neuroscience, University of Washington, Seattle, Washington 98195
}

Activation of $\kappa$ opioid receptors (KORs) produces analgesia and aversion via distinct intracellular signaling pathways, but whether G protein-biased KOR agonists can be designed to have clinical utility will depend on a better understanding of the signaling mechanisms involved. We found that KOR activation produced conditioned place aversion and potentiated CPP for cocaine in male and female C57BL/6N mice. Consistent with this, males and females both showed arrestin-mediated increases in phospho-p38 MAPK following KOR activation. Unlike in males, however, KOR activation had inconsistent analgesic effects in females and KOR increased G $\beta \gamma$-mediated ERK phosphorylation in males, but not females. KOR desensitization was not responsible for the lack of response in females because neither Grk3 nor Pdyn gene knock-out enhanced analgesia. Instead, responsiveness was estrous cycle dependent because KOR analgesia was evident during low estrogen phases of the cycle and in ovariectomized (OVX) females. Estradiol treatment of OVX females suppressed KOR-mediated analgesia, demonstrating that estradiol was sufficient to blunt $G \beta \gamma$-mediated KOR signals. G protein-coupled receptor kinase 2 (GRK2) is known to regulate ERK activation, and we found that the inhibitory, phosphorylated form of GRK2 was significantly higher in intact females. GRK2/3 inhibition by CMPD101 increased KOR stimulation of phospho-ERK in females, decreased sex differences in KOR-mediated inhibition of dopamine release, and enhanced mu opioid receptor and KOR-mediated analgesia in females. In OVX females, estradiol increased the association between GRK2 and G $\beta \gamma$. These studies suggest that estradiol, through increased phosphorylation of GRK2 and possible sequestration of G $\beta \gamma$ by GRK2, blunts G protein-mediated signals.

Key words: analgesia; biased signal transduction; estrogen; kappa opioid receptor; morphine; sex differences

Significance Statement

Chronic pain disorders are more prevalent in females than males, but opioid receptor agonists show inconsistent analgesic efficacy in females. $\kappa$ opioid receptor (KOR) agonists have been tested in clinical trials for treating pain disorders based on their analgesic properties and low addictive potential. However, the molecular mechanisms underlying sex differences in KOR actions were previously unknown. Our studies identify an intracellular mechanism involving estradiol regulation of $\mathrm{G}$ protein-coupled receptor kinase 2 that is responsible for sexually dimorphic analgesic responses following opioid receptor activation. Understanding this mechanism will be critical for developing effective nonaddictive opioid analgesics for use in women and characterizing sexually dimorphic effects in other inhibitory $\mathrm{G}$ protein-coupled receptor signaling responses.

\section{Introduction}

The need for safer treatments for chronic pain is clear from the current crisis in opioid abuse and the growing number of overdose deaths (Volkow and Collins, 2017). G-biased $\kappa$ opioid re-

\footnotetext{
Received March 9, 2018; revised July 11, 2018; accepted July 21, 2018.

Author contributions: A.D.A. wrote the first draft of the paper; A.D.A., S.S.S., B.B.L., and C.C. edited the paper; A.D.A., S.S.S., B.B.L., and C.C. designed research; A.D.A., S.S.S., K.L.R., J.H.C., H.M.F., A.J.S., S.D.J., and B.B.L. performed research; A.D.A., S.S.S., K.L.R., J.H.C., H.M.F., A.J.S., and B.B.L. analyzed data.

This work was supported by the National Institutes of Health (Grants P50 MH106428 and R01 DA030074 to C.C., Grant T32 DA07278 to A.D.A. and K.L.R., Grant T32 NS099578 to K.L.R., and Grant T32 GM007750 to J.H.C. and H.M.F.) and by the Brain \& Behavior Research Foundation (NARSAD Young Investigator Award to B.B.L.). We thank Ashley A. Krull for assistance with ovariectomies.

The authors declare no competing financial interests.

*A.D.A. and S.S.S. contributed equally to this work.
}

ceptor (KOR) agonists are potentially safer analgesics because they lack the addictive properties of mu opioid receptor (MOR) agonists and lack the dysphoric effects of nonbiased KOR agonists (Pfeiffer et al., 1986; Shippenberg and Herz, 1986; Bruchas and Chavkin, 2010; Brust et al., 2016; Chavkin and Koob, 2016). The analgesic effects of KOR agonists occur via G proteinmediated signaling (Land et al., 2009), whereas the dysphoric properties of KOR agonists are dependent on $\mathrm{G}$ protein-coupled receptor kinase 3 (GRK3)/p38 MAPK and $\beta$-arrestin activation

Correspondence should be addressed to Dr. Charles Chavkin, Department of Pharmacology, University of Washington, Box 357280, Seattle, WA 98195-7280. E-mail: cchavkin@uw.edu.

DOI:10.1523/JNEUROSCI.0653-18.2018

Copyright $\odot 2018$ the authors $\quad 0270-6474 / 18 / 388031-13 \$ 15.00 / 0$ 
(Land et al., 2009; Ehrich et al., 2015). This dissociation between the analgesic and dysphoric properties of KOR actions has stimulated the development of $\mathrm{G}$ protein-biased KOR agonists (Brust et al., 2016) and some are in clinical trials for pain and itch disorders (Eisenach et al., 2003; Delvaux et al., 2004).

Chronic pain disorders are more prevalent in women (Berkley, 1997), but KOR agonists have low or inconsistent analgesic efficacy in female humans and rodents (Mogil et al., 2003; Stoffel et al., 2005; Craft, 2008). Female C57BL/6J and DBA/2J mice are significantly less sensitive to the analgesic effects of KOR agonists compared with males (Mogil et al., 2003). Dysphoric effects of prototypical KOR agonists (i.e., U50488) are present in male rodents (Chartoff and Mavrikaki, 2015), but females have doseand species-dependent differences in reactivity to the anhedonic and aversive effects of KOR agonists. Female rats show decreased KOR agonist-mediated suppression of intracranial self-stimulation (Russell et al., 2014), whereas female California mice show conditioned place aversion to a lower dose of U50488 compared with males (Robles et al., 2014). These affective changes produced by KOR agonists are hypothesized to be estrous cycle independent (Russell et al., 2014), but KOR-mediated analgesia has been shown to be modulated by estradiol (Mogil et al., 2003). The present study was designed to identify the intracellular signaling mechanisms responsible for sexually dimorphic analgesic responses to opioid activation with the goal of providing insights to guide the development of better analgesics.

Here, we report that KOR activation produced conditioned place aversion and potentiated cocaine conditioned place preference (CPP) in both male and female C57BL/6N mice, but analgesic effects of KOR activation were attenuated in female mice. The analgesic effects of KOR activation were estradiol sensitive in female mice. We then demonstrated that activation of the estradiolsensitive GRK2 in females increased sequestration of G $\beta \gamma$ and reduced effects of KOR activation on intracellular signaling, inhibition of dopamine release, and agonist-mediated analgesia. Together, these studies identify an estradiol-mediated intracellular signaling mechanism leading to sexually dimorphic responses that may generalize to other $G$ protein-coupled receptors (GPCRs) acting through $\mathrm{G} \alpha \mathrm{i} / \mathrm{o}$ protein signaling mechanisms.

\section{Materials and Methods}

\section{Subjects}

Male and female C57BL/6N (B6) mice $(n=674)$ ranging from $8-16$ weeks of age were used in these experiments. Breeding stocks were maintained in the University of Washington Vivarium and some additional WT animals were obtained from Charles River Laboratories. All experimental procedures were approved by the University of Washington Institutional Animal Use and Care Committee and were conducted in accordance with National Institutes of Health's "Principles of Laboratory Animal Care" (NIH Publication No. 86-23, revised 1985). All testing was during the light phase of the $12 \mathrm{~h}$ light/dark cycle. Prodynorphin (Sharifi et al., 2001) or GRK3 (Peppel et al., 1997) heterozygotes were bred to generate GRK3 $\left(\mathrm{Grk3}^{-1-}\right)$ or PDYN $\left(\mathrm{Pdyn}^{-1-}\right)$ knock-out mice and WT littermates. Mice were genotyped as described previously (McLaughlin et al., 2004; Terman et al., 2004). GRK3 or dynorphin knock-out mice were phenotypically indistinguishable from WT littermates in general locomotor behavior, weight, and lifespan. For estrous cycle determination, vaginal lavage was administered following behavioral testing and cells were placed on glass slides for cytology assessments (McLean et al., 2012).

\section{Drugs}

U50488 (2.5 or $10 \mathrm{mg} / \mathrm{kg})$, norbinaltorphimine $(10 \mathrm{mg} / \mathrm{kg})$, morphine (3 $\mathrm{mg} / \mathrm{kg})$, cocaine $(7.5 \mathrm{or} 15 \mathrm{mg} / \mathrm{kg})$, and 5' GNTI $(0.03 \mathrm{mg} / \mathrm{kg})$ were provided by the National Institute of Drug Abuse (NIDA) Drug Supply
Program (Bethesda, MD) and were dissolved in saline for intraperitoneal administration in a volume of $10 \mathrm{ml} / \mathrm{kg}$. U69593 was purchased from Santa Cruz Biotechnology. Nalfurafine (50 $\mu \mathrm{g} / \mathrm{kg}$; NIDA Drug Supply Program) was dissolved in saline and administered subcutaneously in a volume of $10 \mathrm{ml} / \mathrm{kg}$. The GRK2/3 inhibitor CMPD101 (Tocris Bioscience) was dissolved in $10 \%$ ethanol/10\% Cremaphor EL (Sigma-Aldrich $/ 80 \%$ saline $(15 \mathrm{mg} / \mathrm{kg})$ and administered intraperitoneally in a volume of $10 \mathrm{ml} / \mathrm{kg}$. Estradiol (50 $\mu \mathrm{g} / \mathrm{kg}$; Cayman Chemical) was dissolved in $0.1 \%$ ethanol $/ 0.1 \%$ Cremaphor EL/99\% saline and administered intraperitoneally in a volume of $10 \mathrm{ml} / \mathrm{kg}$.

\section{Procedures}

Conditioned place aversion/preference. Mice were tested for aversion to U50488, a KOR selective agonist (Von Voigtlander and Lewis, 1982), in a two-chamber apparatus with distinct visual and tactile cues as described previously (Ehrich et al., 2015). All conditioning and testing sessions lasted $30 \mathrm{~min}$ and were recorded on video for analysis in Ethovision version 3.0 (Noldus). On day 1 (pretest), mice freely explored each side of the apparatus. Total time on each side was calculated and mice were then conditioned with U50488 $(2.5 \mathrm{mg} / \mathrm{kg})$ paired with their preferred side on subsequent days. On days 2 and 3 (conditioning), mice were confined to one side with saline treatment and, $>4 \mathrm{~h}$ later, confined to the other side following U50488 administration. On day 4, mice were allowed to freely explore each side of the apparatus and time spent on the drug-paired floor during the test was measured. To test cocaine CPP, a three-chamber apparatus was used (McLaughlin et al., 2003). Mice were given a pretest on day 1 and then cocaine was paired with the less preferred side during conditioning on days 2 and 3 . For repeated forced swim stress (rFSS), mice were given a 15 min swim stress $\left(30^{\circ} \mathrm{C}\right)$ following the pretest session and four 6-min swims (separated by 6 min each) $<10$ min before the first cocaine conditioning session, as described previously (McLaughlin et al., 2003). During day 4 (posttest), mice were allowed to freely explore the apparatus. Preference score was determined by subtracting time on the drug-paired compartment during posttest from time on the drug-paired compartment during pretest (post - pre).

Warm water tail withdrawal test. Mice were tested for latency (in seconds) to withdraw tail (flick) from $52.5^{\circ} \mathrm{C}$ water to assess antinociceptive effects of KOR activation (Bruchas et al., 2007a). Mice were tested for basal latency to flick and treated with U50488 (10 mg/kg), morphine $(3 \mathrm{mg} / \mathrm{kg})$, or saline and retested for latency to flick $30 \mathrm{~min}$ later. Doses for U50488 analgesia were selected based on Schattauer et al. (2017). In males, $1.0-7.5 \mathrm{mg} / \mathrm{kg}$ U50488 did not significantly change tail flick latency. Change in latency to flick from the pretest to the posttest was calculated. For experiments with the selective GRK2/3 inhibitor CMPD101 (Thal et al., 2011), mice were tested for basal latency, treated with CMPD101 (1.5 mg/kg), tested 30 min later, treated with U50488 (10 $\mathrm{mg} / \mathrm{kg}$ ) or morphine $(3 \mathrm{mg} / \mathrm{kg}$ ), and retested $30 \mathrm{~min}$ later. Pregnant mice were tested with U50488 before placement with a male and then retested with U50488 at 6 and $13 \mathrm{~d}$ following cohabitation. Investigators were blinded to treatment groups during testing.

Hot plate response test. Mice were tested for latency to paw lick or jump following placement on the hotplate $\left(57.5^{\circ} \mathrm{C}\right)$ immediately before treatment with saline or U50488 (10 mg/kg) and mice were retested $30 \mathrm{~min}$ later, as described previously (Terman et al., 2004). Changes in latency to respond were calculated as the difference between pretest and posttest.

Pruritis. Antipruritic activity of nalfurafine was assayed as described previously (Schattauer et al., 2017). Mice were placed individually in observation boxes with a metal grid floor and were given $1 \mathrm{~h}$ to acclimate. Mice received either saline or nalfurafine ( $50 \mu \mathrm{g} / \mathrm{kg}$, i.p.). Twenty minutes later, mice were injected subcutaneously on the midline of the back of the neck with saline or $5^{\prime}$-GNTI $(0.03 \mathrm{mg} / \mathrm{kg})$ and behavior was recorded on video for $15 \mathrm{~min}$. Hind leg scratches directed to the back of the neck were counted. Data analyses were done by an investigator blinded to sex and drug treatment.

Ovariectomy. Ovaries were removed from female mice (OVX) under isoflurane anesthesia (Smith et al., 2005) and complete removal was visually confirmed. Using mass spectrometry in serum from a subset of OVX mice, we confirmed that circulating estradiol was absent following 
ovariectomy. Mice were allowed 3 weeks for recovery from surgery before behavioral or biochemical experiments. Sham controls receiving surgery without ovary removal were not used in these studies because baseline tail flick scores in ovariectomized females were not different from WT females. For estradiol replacement experiments, mice received a priming injection of $50 \mu \mathrm{g} / \mathrm{kg}$ estradiol $3 \mathrm{~d}$ before testing and then a second injection of $50 \mu \mathrm{g} / \mathrm{kg}$ estradiol $60 \mathrm{~min}$ before behavioral testing or tissue collection (Green et al., 1970).

Isolation of proteins. Mice were decapitated at the specified times following drug administration. Ventral striata, periaqueductal gray (midbrain), and spinal cord were dissected and homogenized with a Dounce homogenizer on ice in MAPK lysis buffer composed of $50 \mathrm{~mm}$ Tris- $\mathrm{HCl}$, $300 \mathrm{~mm} \mathrm{NaCl}, 1 \mathrm{~mm}$ EDTA, $1 \mathrm{~mm} \mathrm{Na} \mathrm{VO}_{4}, 1 \mathrm{~mm} \mathrm{NaF}, 10 \%$ glycerol, protease inhibitor cocktail (Sigma-Aldrich), and phosphatase inhibitor cocktail (Millipore). For analysis of GRK2 protein levels, lysis buffer was supplemented with $1 \%$ Triton X-100. Samples were centrifuged $25 \mathrm{~min}$ at $30,000 \times g$ at $4^{\circ} \mathrm{C}$. Protein concentrations in supernatant were determined by bicinchoninic colorimetric assay (Thermo Fisher Scientific), mixed with $4 \times$ LDS buffer (10\% lithium dodecyl sulfate, $25 \%$ glycerol, $\mathrm{pH}$ 8.4; Thermo Fisher Scientific) supplemented with $8 \% \beta$-mercaptoethanol and stored at $-20^{\circ} \mathrm{C}$ until analysis by western blot.

Western blot analysis. Samples were loaded with $30 \mu \mathrm{g}$ of protein (phospho-ERK1/2) or $40 \mu \mathrm{g}$ of protein (phospho-p38 MAPK) onto $10 \%$ Bis-Tris precast gels (Thermo Fisher Scientific) and run at $100 \mathrm{~V}$ for $2 \mathrm{~h}$. Blots were transferred to nitrocellulose (Thermo Fisher Scientific) for $1.5 \mathrm{~h}$ at $30 \mathrm{~V}$. The nitrocellulose was blocked with 5\% BSA-TBS $1 \mathrm{~h}$ at room temperature and stained overnight at $4^{\circ} \mathrm{C}$ for phospho-ERK1/2 (Cell Signaling Technology \#cs9101, RRID:AB_331646, lot 28, 1:1000) and ERK2 (Santa Cruz Biotechnology \#sc1647, RRID:AB_627547, 1:2000), phospho-p38 (Cell Signaling Technology \#cs9211, RRID: AB_331641, lot 23, 1:1000) and p38 $\alpha$ (Cell Signaling Technology \#cs9228, RRID:AB_490886, lot 2, 1:1000), or phospho-GRK2(S670) (Sigma-Aldrich \#MABS155, lot 2792488, 1:250) and GRK2 (SigmaAldrich \#SAB4500592, lot 218278, 1:500) in 5\% BSA-TBS. Blots were incubated in IRdye secondary (Li-Cor Biosciences \#926-68070 lot C50721-05 and \#926-32211 lot C506602-05, 1:10,000) in 1:1 Odyssey buffer (Li-Cor) and 5\% milk-TBS $1 \mathrm{~h}$ at room temperature and then scanned on the Odyssey Infrared Imaging System (Li-Cor Biosciences). Band intensity was measured using the Odyssey software and expressed as phospho-immunoreactive protein intensity over the homologous protein band intensity. For total protein quantification, protein was normalized to Revert protein stain (Thermo Fisher Scientific). Data were normalized to percentage of control sample (saline, 100\%). The G $\beta$ antibody detected a single band at $37 \mathrm{kDa}$. ERK1/2 and phospho-ERK1/2 antibodies each detected two bands at 42 and $44 \mathrm{kDa}$. The antibody for p38 $\alpha$ identified a single band at the predicted weight of $\sim 42 \mathrm{kDa}$. In addition to the expected band, the phospho-p38 antibody also detected nonspecific bands at $\sim 45 \mathrm{kDa}$; only the band overlapping with the $\mathrm{p} 38 \alpha$ band was quantified (Bruchas et al., 2007b). The GRK2 antibody detected bands at the predicted weight of $\sim 80 \mathrm{kDa}$ and at $\sim 55 \mathrm{kDa}$, whereas the phospho-GRK2 antibody detected multiple nonspecific bands, but a single band at $\sim 80 \mathrm{kDa}$; the $\sim 80 \mathrm{kDa}$ band was identified as the specific band by GRK2 overexpression in HEK293 cells combined with phorbol-12-myristate-13-acetate treatments (Pitcher et al., 1999).

Coimmunoprecipitation. Mice were decapitated at the specified times following drug administration. Ventral striata and spinal cord were dissected and homogenized with a Dounce homogenizer on ice in coimmunoprecipitation buffer ( $20 \mathrm{~mm}$ Tris, $135 \mathrm{~mm} \mathrm{NaCl}, 0.5 \mathrm{~mm}$ EDTA, $10 \mathrm{~mm}$ sodium fluoride, $1 \mathrm{~mm}$ sodium orthovanadate, $1 \%$ Triton X-100, 10\% glycerol, protease inhibitor cocktail (Sigma-Aldrich), and phosphatase inhibitor cocktail (Millipore), pH 7.5. Next, $700 \mu \mathrm{g}$ of protein was incubated overnight at $4^{\circ} \mathrm{C}$ with $5 \mu$ l GRK2 antibody (Cell Signaling Technology \#cs3982, RRID:AB_330680, lot 1) before incubation for $2 \mathrm{~h}$ with $25 \mu \mathrm{l}$ washed magnetic protein A/G beads (Thermo Fisher Scientific) at $4^{\circ} \mathrm{C}$. Samples were washed twice with buffer before elution at room temperature with $40 \mu \mathrm{l}$ of $4 \times$ LDS. Samples were loaded onto $4-12 \%$ BisTris precast gels (Thermo Fisher Scientific) and analyzed as described above, blotting for GRK2 (as above) and G $\beta$ (Santa Cruz Biotechnology \#sc-378, RRID:AB_2159943, lot C0515, 1:500) band intensity was normalized to GRK2 band intensity.

qRT-PCR analysis of KOR and GRK2 mRNA levels. Mice were decapitated and ventral striata were dissected on ice. RNA was isolated using the Qiashredder and RNeasy Plus Mini Kits (Qiagen). RNA was amplified on a Stratagene Mx3000P (Agilent) using the Thermo Power SYBR Green RNA-to-CT 1-Step Kit (Thermo Fisher Scientific) according to the manufacturer's instructions, with the standard cycle settings: $50^{\circ} \mathrm{C} 30 \mathrm{~min}$, $95^{\circ} \mathrm{C} 5 \mathrm{~min}, 40 \times\left(95^{\circ} \mathrm{C} 15 \mathrm{~s}, 62^{\circ} \mathrm{C} 1 \mathrm{~min}\right.$, followed by a dissociation curve ramping from $95^{\circ} \mathrm{C}$ to $55^{\circ} \mathrm{C}$ and back to $95^{\circ} \mathrm{C}$. For KOR, the following primers were used: GTGGGCTTAGTGGGCAATTCT, AGTGGTAGTAACCAAAGCATCTG. For GRK2, the following primers were used: GCGCCAGCAAGAAGATCCT, GCAGAAGTCCCGGAAAAGCA. PPIA was selected as a reference gene after experiments demonstrated no difference in expression between male and female mice using the following primers: CACCGTGTTCTTCGACATCA and CAGTGCTCAGAGCTCGAAAGT. All samples were run in duplicate (20 ng of RNA) with a standard curve on each plate. Data were analyzed with the MxPro version 3.20 software (Agilent Technologies). Transcript levels were calculated from the standard curve, with KOR and GRK2 transcript levels then normalized to PPIA transcript levels.

Voltammetry. Mice were decapitated and the head placed in preoxygenated, cold modified artificial CSF (aCSF) (248 mm sucrose was substituted for $\mathrm{NaCl}$ ). The brain was removed and $250 \mu \mathrm{m}$ coronal slices containing nucleus accumbens were prepared. To measure evoked dopamine release, nucleus accumbens slices were transferred to standard oxygenated aCSF and incubated for $1 \mathrm{~h}$ at $37^{\circ} \mathrm{C}$ before holding at room temperature before recordings. Slices were placed in a recording chamber and perfused with oxygenated aCSF ( $124 \mathrm{~mm} \mathrm{NaCl}, 2.5 \mathrm{~mm} \mathrm{KCl}, 1.25$ mM NaH${ }_{2} \mathrm{PO}_{4}, 1.25 \mathrm{~mm} \mathrm{MgSO}_{4}, 2 \mathrm{~mm} \mathrm{CaCl}_{2}, 10 \mathrm{~mm}$ dextrose, $25 \mathrm{~mm}$ $\mathrm{NaHCO}_{3}$ ) at $31-33^{\circ} \mathrm{C}$ throughout recording. Carbon-fiber working electrodes were fabricated as described previously (Clark et al., 2010; Lemos et al., 2012) hand-cut to $150-200 \mu \mathrm{m}$ past the capillary tip. A single electric pulse (120-200 $\mu \mathrm{A}, 2 \mathrm{~ms}$ per phase) was applied to a parallel bipolar stimulating electrode to evoke dopamine release and the potential at the working electrode was held at $-0.4 \mathrm{~V}$ versus $\mathrm{Ag} / \mathrm{AgCl}$ and ramped to $+1.3 \mathrm{~V}$ and back to $-0.4 \mathrm{~V}$ at a rate of $10 \mathrm{~Hz}$. Baseline dopamine release was measured every $2 \mathrm{~min}$ for $20 \mathrm{~min}$ before measuring release after stepwise increasing concentrations of U69593 (20 min per concentration). For CMPD101 experiments, aCSF with $30 \mu \mathrm{M}$ CMPD101 was washed onto the slice for $10 \mathrm{~min}$ before washing on both $30 \mu \mathrm{M}$ CMPD101 and increasing doses of U69593. Waveform generation, data acquisition, and analysis were performed using two PCI multifunction data acquisition cards and software written in LabVIEW version 7.1 (National Instruments) as described previously (Clark et al., 2010; Lemos et al., 2012). Responses in the last $8 \mathrm{~min}$ (4 recordings) were used for generating U69593 concentration curves in GraphPad Prism software and fitted using a three-parameter least-squares nonlinear regression with the top constrained to $100 \%$ and the Hill slope constrained to -1 .

\section{Experimental design and statistical analysis}

Animal numbers were as follows: conditioned place aversion, $n=13-16$ per group; CPP, $n=7-19$ per group; tail flick, $n=3-6$ per group for males and $n=7-19$ per group for females; time course for tail flick, $n=$ 6; hot plate, $n=6-9$ per group; pruritis, $n=10-15$ per group; dynorphin/GRK3 knock-out tail flick, $n=5-6$ per group; OVX/estradiol replacement tail flick, $n=8-9$ per group; striatal pERK, $n=8$ per group; striatal p38, $n=8-11$ per group; midbrain $\mathrm{pERK}, n=4-5$ per group; striatal GRK2 expression, $n=8$ per group; phospho-GRK2, $n=11-13$ per group; spinal cord $\mathrm{pERK} / \mathrm{p} 38, n=7-9$; GRK2/G $\beta$ coimmunoprecipitation, $n=8-10$ per group; CMPD101/phospho-ERK, $n=3-4$ per group; dopamine voltammetry, $n=5-9$ per group; CMPD101/U50488 tail flick, $n=13$; CMPD101/Grk3 ${ }^{-1-}, n=9-14$ per group; and CMPD101/morphine tail flick, $n=8$ per group. Data are expressed as mean \pm SEM and were analyzed with Prism 7 software (GraphPad). For $\mathrm{EC}_{50}, 95 \%$ confidence intervals (95\% CIs) are reported. Group differences were determined using $t$ tests, ANOVA, or repeated-measures 
ANOVA as described in the Results. Post hoc comparisons were analyzed with Dunnett's or Sidak's test. For all statistical tests, $\alpha$ was set to 0.05 .

\section{Results \\ KOR activation in females produces aversion but not analgesia}

In male $\mathrm{B} 6$ mice, KOR activation stimulates $\mathrm{G} \alpha \mathrm{i} / \mathrm{G} \beta \gamma$ signaling to produce analgesia and decrease itch, whereas arrestindependent signaling produces aversion and increases drugseeking behaviors (Ehrich et al., 2015; Schattauer et al., 2017). We first tested for sex differences in arrestin-mediated behaviors following KOR activation. U50488, an unbiased KOR agonist (Von Voigtlander and Lewis, 1982; Schattauer et al., 2012), produced conditioned place aversion in male and female B6 mice $(2.5 \mathrm{mg} /$ kg; Fig. $1 A)$. There was a main effect of $\operatorname{drug}\left(F_{(1,52)}=12.32, p=\right.$ $0.009)$ and no main effect of sex or interaction between sex and drug. Planned comparisons between the saline- and U50488treated mice showed a significant effect of U50488 in males ( $p=$ 0.027 ) and females $(p=0.02)$. As previously reported, females were more sensitive to the CPP effects of cocaine than males (Russo et al., 2003); significant cocaine CPP was evident in female mice at $7.5 \mathrm{mg} / \mathrm{kg}$, whereas $15 \mathrm{mg} / \mathrm{kg}$ was required for males (Fig. $1 B$ ). This was confirmed with a one-sample $t$ test showing that 7.5 $\mathrm{mg} / \mathrm{kg}$ cocaine in unstressed males was not significantly different from a preference score of 0 , whereas unstressed females ( 7.5 or $15 \mathrm{mg} / \mathrm{kg} ; p<0.0001)$ and unstressed males $(15 \mathrm{mg} / \mathrm{kg} ; p=$ 0.009 ) were significantly different from 0 . rFSS has been shown to produce a KOR-dependent increase in cocaine-seeking behaviors (McLaughlin et al., 2003) and these effects are GRK3/arrestin dependent (Schindler et al., 2012). Stress potentiated cocaine CPP in both males and females (Fig. 1B). A 3-way ANOVA showed that there was no main effect of sex, but there was a main effect of cocaine dose $\left(F_{(1,115)}=79.9, p<0.001\right)$ and stress $\left(F_{(1,115)}=7.14, p=0.009\right)$. There was also a significant interaction between sex and dose $\left(F_{(1,115)}=33.9, p<0.001\right)$, with both males $(p<0.001)$ and females $(p=0.011)$ showing significant differences in preference scores between $15 \mathrm{mg} / \mathrm{kg}$ and $7.5 \mathrm{mg} / \mathrm{kg}$ of cocaine. These conditioned place aversion and stress-potentiated cocaine CPP studies indicated that arrestin-mediated behavioral effects of KOR activation were present in both males and females.

We then tested G $\beta \gamma$-mediated behaviors and found that KOR activation produced significant antinociceptive responses in the tail flick assay in males, but not females. In the tail flick assay (Fig. $1 C)$, there was a significant interaction between sex and drug treatment $\left(F_{(1,43)}=4.71, p=0.036\right)$. Post hoc analyses showed that males treated with KOR agonist had a significant increase in latency to flick compared with saline-treated males $(p=0.008)$ and were significantly different from females treated with KOR agonist $(p=0.049)$. Repeated testing of tail flick analgesia in females at $10 \mathrm{~min}$ intervals for $60 \mathrm{~min}$ following U50488 administration did not reveal any significant effect of drug treatment (Fig. 1D). Higher doses of U50488 were not tested in females because doses of up to $30 \mathrm{mg} / \mathrm{kg}$ do not produce significant analgesia in female C57BL/6 mice (Mogil et al., 2003). To interrogate alternative antinociceptive circuits, we next used the hot plate assay and confirmed that KOR-mediated analgesia was also absent in female mice in this assay of analgesia (Fig. 1E). There was a significant interaction between drug treatment and $\operatorname{sex}\left(F_{(1,26)}=12.2, p=0.002\right)$ on hot plate response latency. Males treated with U50488 (10 mg/kg) had significantly different response latencies from saline-treated males $(p=$
$0.0002)$ and females treated with U50488 $(p=0.001)$ in the hot plate assay.

To determine whether females showed antipruritic (anti-itch) effects of KOR activation, another hypothesized G proteinmediated behavior (Schattauer et al., 2017), we tested the G-biased KOR agonist nalfurafine $(50 \mu \mathrm{g} / \mathrm{kg})$ in males and females following application of $5^{\prime}$-GNTI, a KOR antagonist that induces compulsive scratching behaviors (Inan et al., 2011). We found that 5 '-GNTI produced equivalent baseline levels of scratching behaviors in males and females and that significant antipruritic effects of nalfurafine were observed in both male and female mice (Fig. $1 F$ ). There was a significant interaction between sex and nalfurafine treatment $\left(F_{(1,46)}=4.05, p=0.05\right)$. Post hoc analyses showed that nalfurafine significantly decreased scratching in males $(p<0.0001)$ and females $(p=0.0005)$ compared with vehicle controls. These studies demonstrate that KOR produces arrestin-dependent behavioral effects in male and female B6 mice, but some $\mathrm{G}$ protein-mediated effects are differentially regulated in males and females.

\section{Lack of antinociceptive response to KOR activation in females is estrogen sensitive and is not attributable to KOR desensitization}

We tested whether KOR activation in females had greater intrinsic bias toward arrestin-mediated signaling by global deletion of the GRK3 (Bruchas et al., 2006). We hypothesized that deletion of arrestin-mediated KOR signals would uncover analgesic responses if basal receptor desensitization was elevated in females. However, GRK3 deletion $\left(G r k 3^{-I^{-}}\right)$did not alter analgesic responses in female mice (Fig. 2A). We then tested whether altered basal dynorphin tone may contribute to the sexually dimorphic behavioral effects of KOR activation through receptor desensitization and found that global deletion of dynorphin $\left(P d y n^{-1-}\right)$ did not produce KOR-mediated analgesic responses in female mice (Fig. 2A).

The sensitivity to KOR activation in the tail flick assay was estrous-cycle-dependent (Fig. 2B). Females were divided into estrus (low estrogen) or nonestrus groups and females in estrus showed significantly greater analgesia $\left(t_{(23)}=2.14, p=0.043\right)$ in response to KOR activation (Fig. $2 B$ ). To confirm the necessity of circulating gonadal hormones for KOR-mediated analgesia (Mogil et al., 2003), we assessed analgesia 3 weeks following OVX and found a significant effect of OVX on KOR-mediated analgesia in the tail flick assay $\left(F_{(3,51)}=5.05, p=0.004\right)$. Compared with intact females treated with KOR agonist, OVX females treated with KOR agonist showed a significant increase in tail flick analgesia $(p=0.009)$. Systemic administration of $17 \beta$ estradiol in OVX females impaired KOR-mediated analgesia compared with OVX females $(p=0.02)$ (Fig. $2 C)$. There was no significant effect of OVX or $17 \beta$-estradiol on baseline latency to respond. These studies demonstrated that estrogen was necessary and sufficient to blunt KOR-mediated analgesia. To assess KOR-mediated analgesia during pregnancy, a period of altered hormone circulation (McCormack and Greenwald, 1974), we tested analgesia at multiple time points immediately before and following pair housing females with males. Thirteen days following pairing with a male, KORmediated analgesia was observed in the tail flick assay in female mice. A repeated-measures ANOVA confirmed this observation with a main effect of treatment $\left(F_{(1.66,19.9)}=6.02\right.$, $p=0.01)$ and post hoc analyses showed that day 13 was significantly different $(p=0.024)$ from day 0 females (Fig. $2 D)$. 

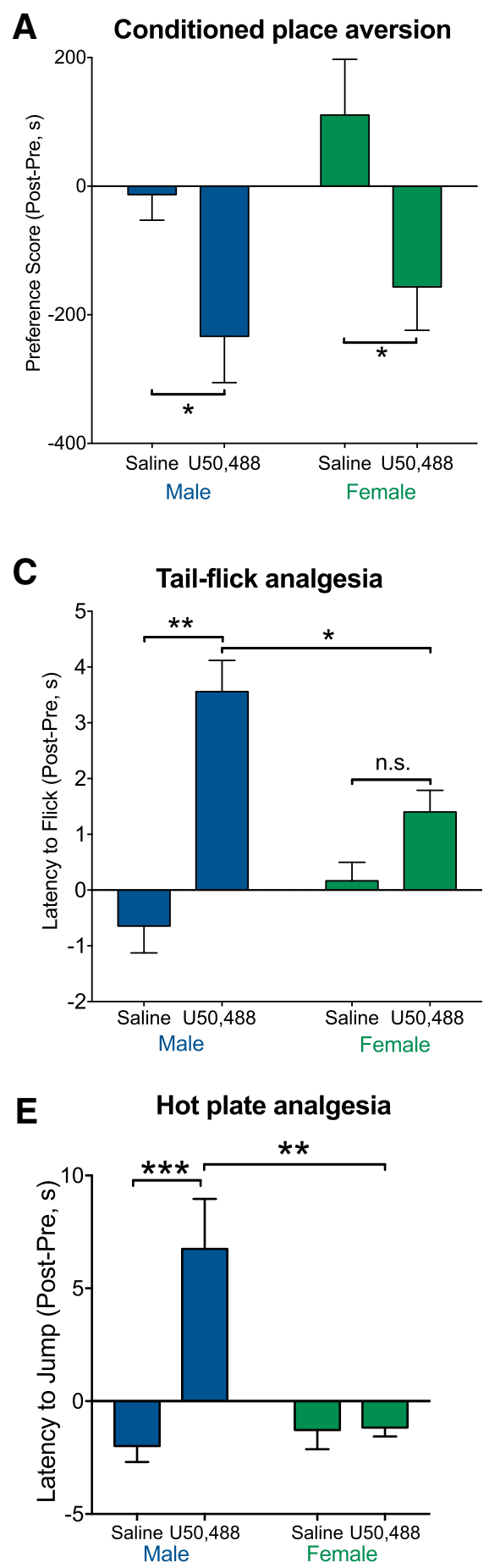

\section{B \\ Stress potentiation of \\ cocaine reward}

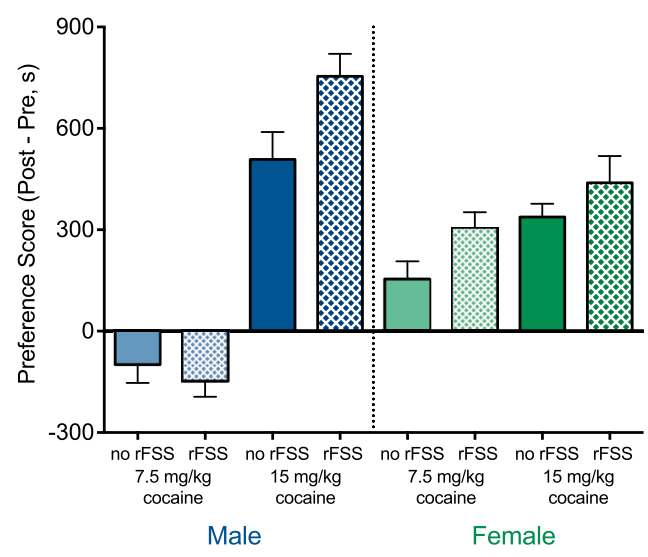

D Tail-flick analgesia

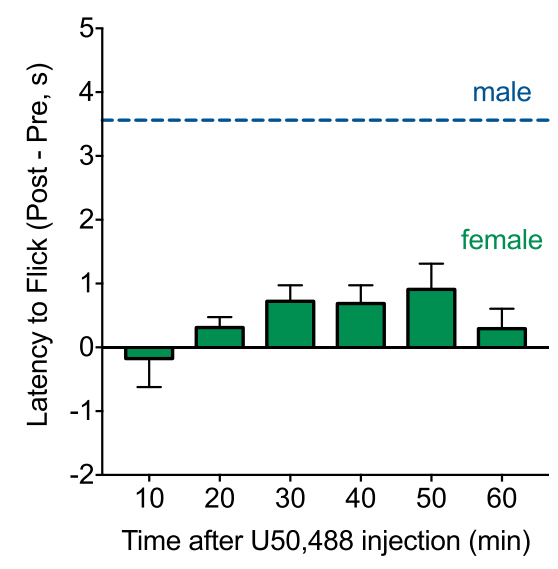

$\mathbf{F}$

Pruritis

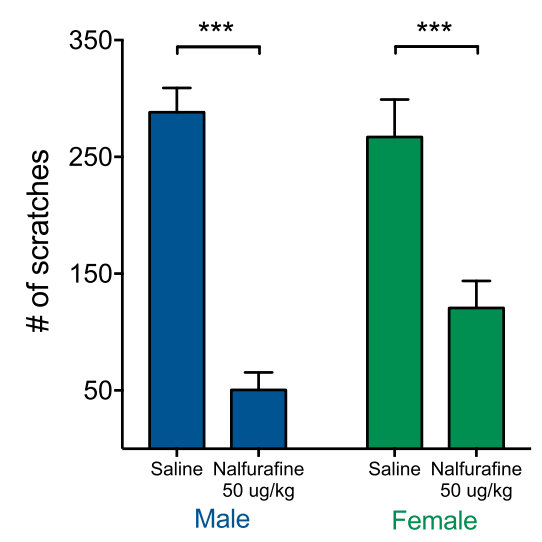

Figure 1. KOR activation in females produces aversion, but not analgesia. $A$, Conditioned place aversion to U50488 (2.5 mg/kg) was observed in both males and females ( $n=13-16$ per group) compared with saline-treated mice (males $p<0.05$; females $p<0.05$ ). B, Consistent with prior reports (Russo et al., 2003), female mice were more sensitive than males to cocaine conditioning. rFSS (cross-hatched bars) increased cocaine preference ( $n=7-19$ per group) in males conditioned with $15 \mathrm{mg} / \mathrm{kg}$ cocaine and females with $7.5 \mathrm{mg} / \mathrm{kg}$ cocaine. There was no significant effect of sex on cocaine CPP potentiation, but there was a significant main effect of stress and a significant interaction between sex and dose. C, U50488, but not saline, increased latency to tail withdrawal in males ( $n=3$ saline, $n=6$ U50488; $p<0.01$ ) in a warm water tail flick assay, but U50488 treatment of females produced a small increase latency that was not significantly different from saline-treated mice ( $n=11$ saline, $n=27$ U50488). Latency to flick was significantly different between males and females treated with U50488 $(p<0.05)$. $D$, To assess whether the lack of effect at 30 min after injection was due to a difference in the pharmacokinetics of U50488, female mice were tested every 10 min and showed no significant effect at any time during the 60 min $(n=6)$. $E$, Using the hot plate to interrogate different analgesic circuits, males treated with U50488 ( $n=6-9$ per group) showed a significant $(p<0.001)$ increase in latency to jump/lick in the hot plate assay compared with saline treatment and were significantly different $(p<0.001)$ from U50488-treated females. $\boldsymbol{F}$, Following application of $5^{\prime}$ GNTI, a compound that induces compulsive scratching (Inan et al., 2011), males and females $(n=13 ; n=12)$ treated with nalfurafine $(50 \mu \mathrm{g} / \mathrm{kg})$, a KOR agonist, had significantly decreased $(p<0.0001 ; p<0.001)$ scratching behaviors compared with saline-treated males or females $(n=15 ; n=10)$. Error bars indicate SEM. ${ }^{*} p<0.05,{ }^{* *} p<0.01$, ${ }^{* * *} p<0.001$, n.s., not significant. 


\section{A}
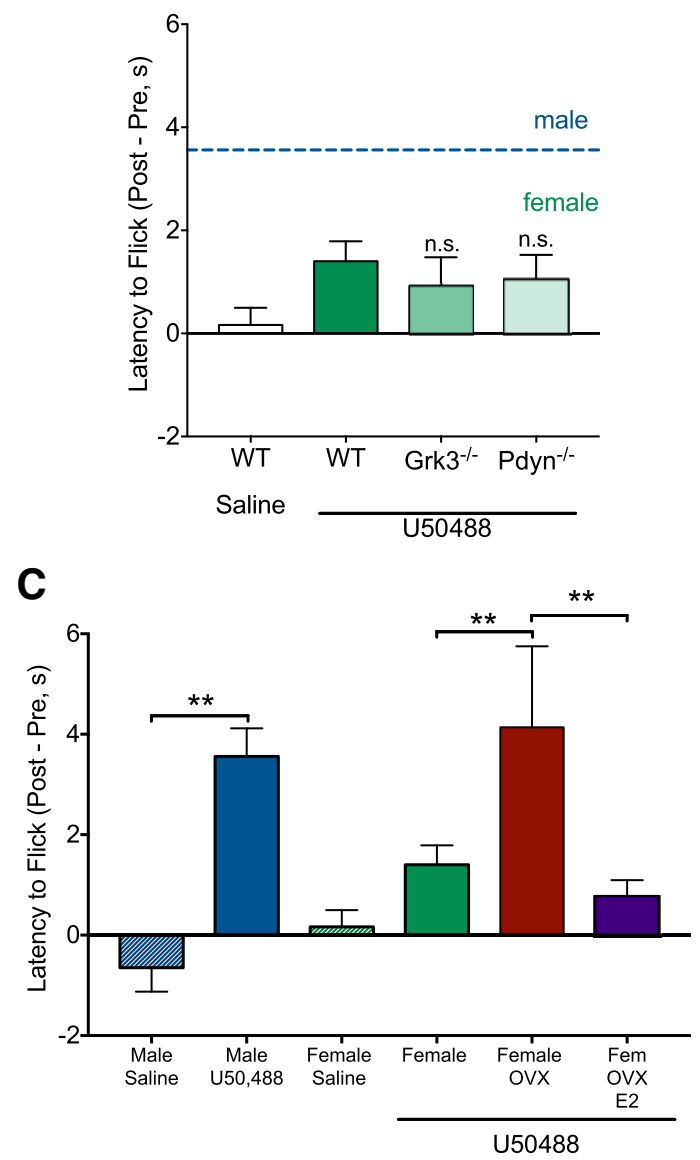

B
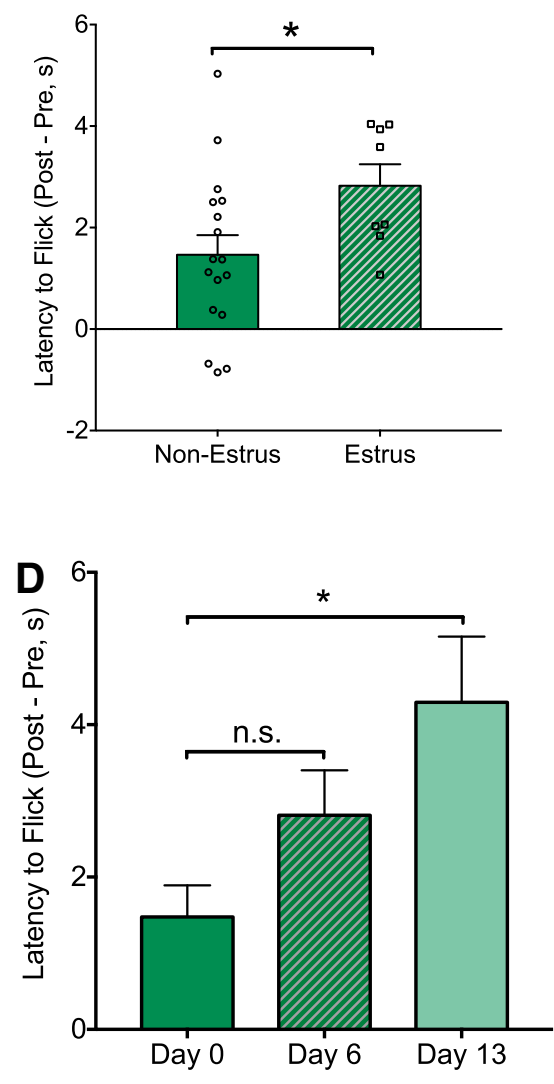

Figure 2. Lack of antinociceptive response to KOR activation in females is estrogen sensitive and is not attributable to KOR desensitization. $\boldsymbol{A}$, U50488 treatment of female GRK3 knock-0ut $\left(G r k 3^{-1-}, n=4\right)$ and dynorphin knock-out (Pdyn $\left.{ }^{-1-}, n=5\right)$ mice did not increase tail withdrawal latencies. WT female data are replotted from Figure $1 C$ for analysis in $\boldsymbol{A}, \boldsymbol{B}$, and $\boldsymbol{C}$. $\boldsymbol{B}$, WT females ( $n=25$ ) were assessed for cycle following tail flick and divided into high estrogen (diestrus/proestrus/metestrus; $n=17$ ) or low estrogen (estrus; $n=8$ ) groups. KOR activation produced significantly greater $(p<0.05)$ antinociception in the low estrogen group compared with the high estrogen group. $C$, Male and intact female data are replotted from Figure $1 C$ for comparison with OVX females $(n=8)$. OVX significantly increased ( $p<0.01$ ) analgesic response to KOR activation and systemic $17 \beta$-estradiol treatment (E2; $50 \mu \mathrm{g} / \mathrm{kg} ; 0.1 \%$ ethanol/0.1\% Cremaphor EL/99\% saline; Cayman Chemical) in OVX females $(n=9)$ significantly $(p<0.01)$ blunted KOR-mediated analgesia compared with OVX females. $\boldsymbol{D}$, Tail flick latencies were significantly increased during pregnancy on day 13 compared with prepregnancy responses to KOR activation. $(p<0.05)$ Error bars indicate SEM. ${ }^{*} p<0.05,{ }^{* *} p<0.01$, n.S., not significant.

\section{KOR activation produces $\mathrm{p} 38 \mathrm{MAPK}$ phosphorylation in males and females but not ERK 1/2 phosphorylation in females}

To determine whether differences in KOR signaling could be due to altered basal expression of KOR, we measured levels of KOR mRNA in males and females using qRT-PCR in ventral striatal extracts. We found no significant differences in male and female KOR mRNA in the striatum (Fig. 3A). Based on our behavioral data and Robles et al. (2014), we hypothesized that KOR activation should produce arrestin-mediated signals in males and females, but $G$ protein-mediated signals should not be present in females. Western blot analysis demonstrated that there was a significant effect of KOR activation on phosphorylation of striatal p38 MAPK $\left(F_{(1,34)}=12.35, p=0.001\right)$, with no effect of sex and no interaction (Fig. 3B). In contrast, there was no main effect of KOR agonist on striatal ERK1/2 phosphorylation (Fig. 3C), but there was an interaction between sex and $\mathrm{KOR}$ agonist $\left(F_{(3,37)}=\right.$ $4.98, p=0.005)$. There was no significant difference in total ERK1/2 (males $=102 \pm 9 \%$; females $=98 \pm 7 \%$ of average expression) or total p38 (males $=112 \pm 17 \%$; females $=88 \pm$ $17 \%$ of average expression) protein levels. Post hoc analyses showed that ERK1/2 phosphorylation in males treated with
U50488 were significantly different from saline-treated males $(p=0.007)$ and from females treated with KOR agonist $(p=$ 0.0003 ), whereas U50488 treatment did not significantly increase striatal pERK in females (Fig. 3C). Representative Western blots for Figure 3, $A-C$, are shown in Figure 3, $D$ and E. Representative blots for Figure 3, $G$ and $H$, are shown in Figure 3F. Western blot analysis of spinal cord extracts 30 min following systemic U50488 $(10 \mathrm{mg} / \mathrm{kg})$ administration showed increased p38 phosphorylation in spinal cord in males and females $\left(F_{(1,30)}=5.97, p=\right.$ 0.021 ), with no significant effect of sex or interaction between sex and treatment (Fig. 3G). U50488 significantly increased pERK in males but not females at $30 \mathrm{~min}$, with a significant interaction between sex and treatment $\left(F_{(1,29)}=14.38, p=0.019\right)$. Post hoc analysis showed that saline-treated males were significantly different from U50488-treated males $(p=0.038)$. There was no significant effect on $\mathrm{pERK}$ at $15 \mathrm{~min}$ in males or females, suggesting an altered time course for KOR signaling in the spinal cord compared with brain tissue. In midbrain samples targeted to include the periaqueductal gray, a region known to mediate opioid analgesia, p38 phosphorylation ( $n=7-9)$ at 30 min was nonsignificantly increased in males ( $132 \pm 22 \%$ of average expression) compared with females (104 $\pm 20 \%$ of average expression). Sim- 
A

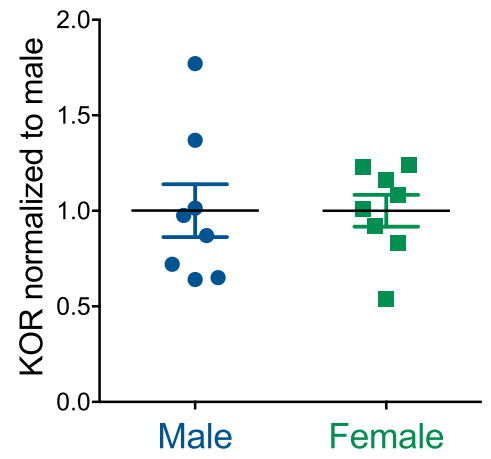

D

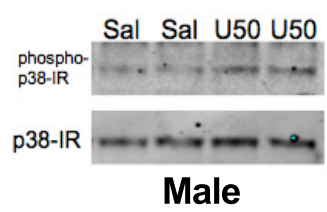

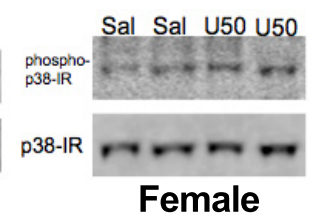

B

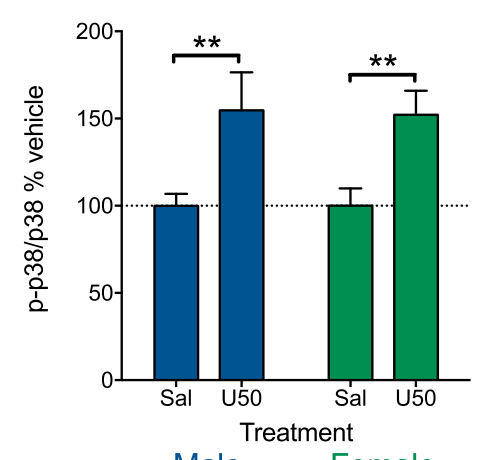

Male Female

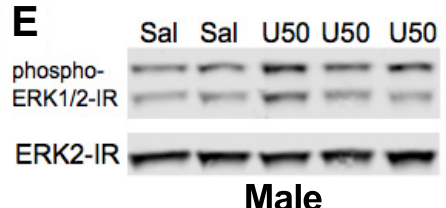

p38 phosphorylation ventral striatum

Male
ERK1/2 phosphorylation ventral striatum
C

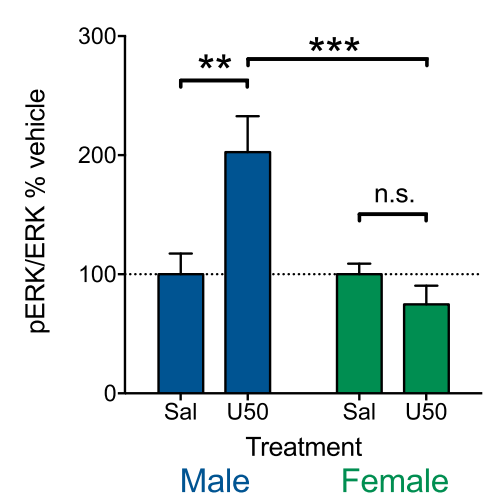

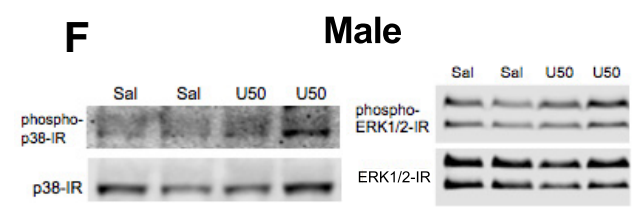

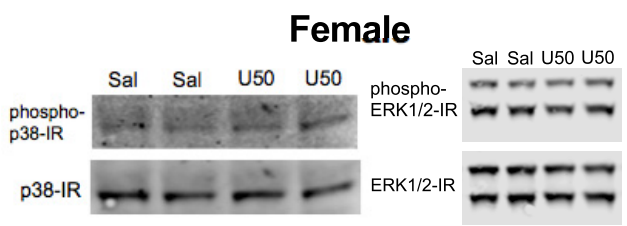

\section{G}

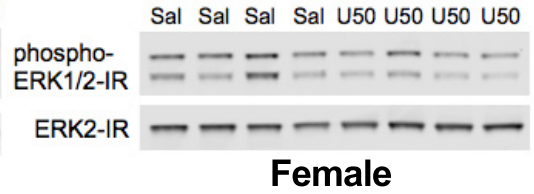

\section{H ERK1/2 phosphorylation spinal cord}

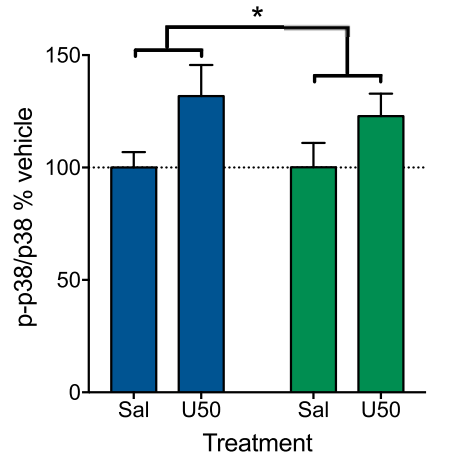

Male Female

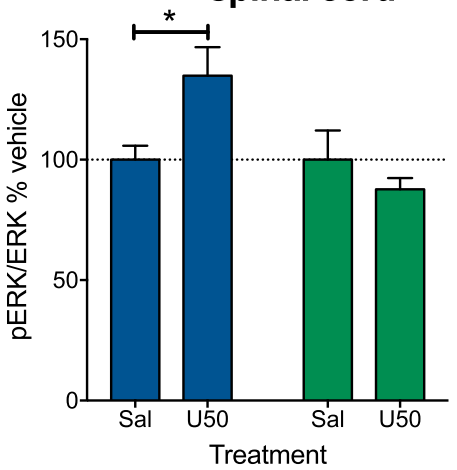

Male Female

Figure 3. KOR activation produces p38 MAPK phosphorylation in males and females, but not ERK $1 / 2$ phosphorylation in females. $\boldsymbol{A}$, Striatal mRNA from male and female mice was isolated and analyzed for KOR expression by qRT-PCR. No difference in KOR expression was observed ( $n=8$ per group) (B,C). Mice were injected with U50488 (10 mg/kg, i.p.) or saline 15 or 30 min before isolating striatal proteins. Phosphorylation of p38 (B) and ERK1/2 phosphorylation $(\boldsymbol{C})$ in ventral striatum of male and female mice by Western blot analysis is shown. $\boldsymbol{B}$, U50488 induced p38 phosphorylation in male and female mice. There was a significant effect of U50488 ( $p<0.001$ ), with no difference between males ( $n=11$ ) and females ( $n=8$ ). $\boldsymbol{C}$, U50488 induced ERK1/2 phosphorylation $(p<0.001)$ in male $(n=5-6)$ but not female $(n=8)$ mice and males were significantly different from females $(p<0.001)$. $\boldsymbol{D}$, Representative blots for $\boldsymbol{B}$. $\boldsymbol{E}$, Representative blots for $\boldsymbol{C}$. $\boldsymbol{F}$, Representative blots for $\boldsymbol{G}$ and $\boldsymbol{H}$. G, U50488 induced p38 phosphorylation in male and female mice ( $n=7-9$ per group) in spinal cord homogenates (bracket indicates main effect of treatment; $p<0.05)$. $\boldsymbol{H}$, U50488 induced ERK phosphorylation in male $\left(n=7-9\right.$ per group) but not female $\left(n=9\right.$ per group) mice $(p<0.05)$. Error bars indicate SEM.* $p<0.05,{ }^{* *} p<0.01$, ${ }^{* * *} p<0.001$, n.S., not significant.

ilar to p38 phosphorylation, pERK $(n=4-5)$ at 15 min was also nonsignificantly increased in males $(144 \pm 21 \%$ of average expression) compared with females $(74 \pm 20 \%$ of average expression) in the midbrain.

GRK2 sequesters G $\beta / \gamma$ to decrease KOR-mediated ERK phosphorylation and dopamine release inhibition in females G protein-coupled receptor kinase 2 (GRK2) can be modulated by estradiol via phosphorylation of the S670 GRK2 site (Dominguez et al., 2009) and GRK2 can sequester components of signaling pathways upstream from ERK1/2 phosphorylation, including G $\beta \gamma$ and MEK (Daaka et al., 1997; Pitcher et al., 1999; Raveh et al., 2010). GRK2 activity can blunt KOR-mediated effects in cardiac tissue (Chen et al., 2017), suggesting that there may be direct interactions between GRK2 and KOR in the brain. Using qRTPCR in striatal extracts, we determined that total GRK2 levels were not significantly different between males and females (Fig. $4 A$ ). However, phosphorylation of the estrogen target $\$ 670$ site of GRK2 was significantly greater in females $\left(t_{(22)}=2.64, p=0.034\right)$ compared with males (Fig. $4 B$ ) and there was an estradiolsensitive increase in GRK2 association with G $\beta$ in ovariectomized females (Fig. 4C). There was a significant effect of GRK2 coimmunoprecipitation compared with input $\left(F_{(1,31)}=10.01\right.$, $p=0.004)$ and a significant interaction between sample group and estradiol treatment $\left(F_{(1,31)}=10.74, p=0.003\right)$. Post hoc analysis showed that estradiol treatment significantly increased $(p=0.005)$ coimmunoprecipitation between GRK2 and G $\beta \gamma$ in the immunoprecipitate, but not in the input sample. A similar 
A

GRK2 mRNA

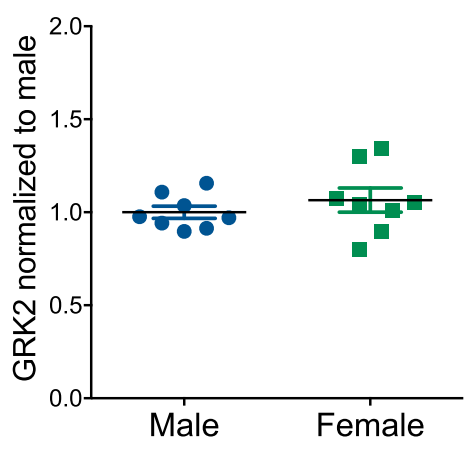

C

GRK2-G $\beta$ coimmunoprecipitation

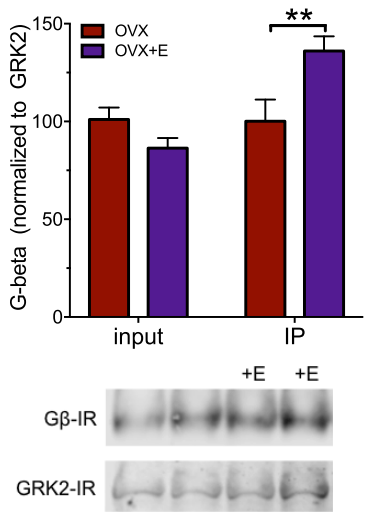

E
B

GRK2 S670 phosphorylation

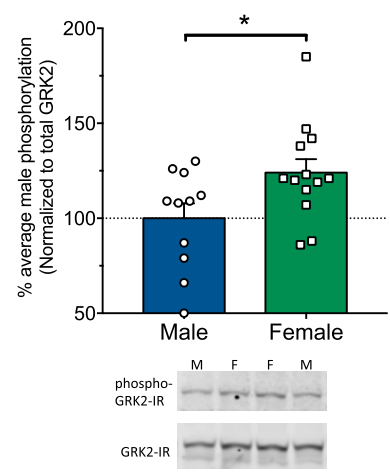

D ERK1/2 phosphorylation

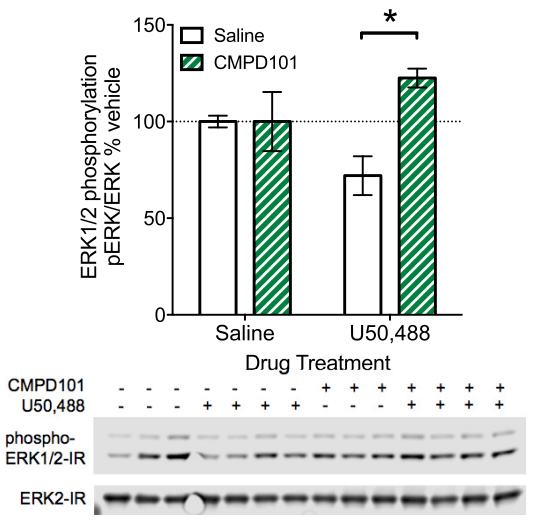

$\mathbf{F}$
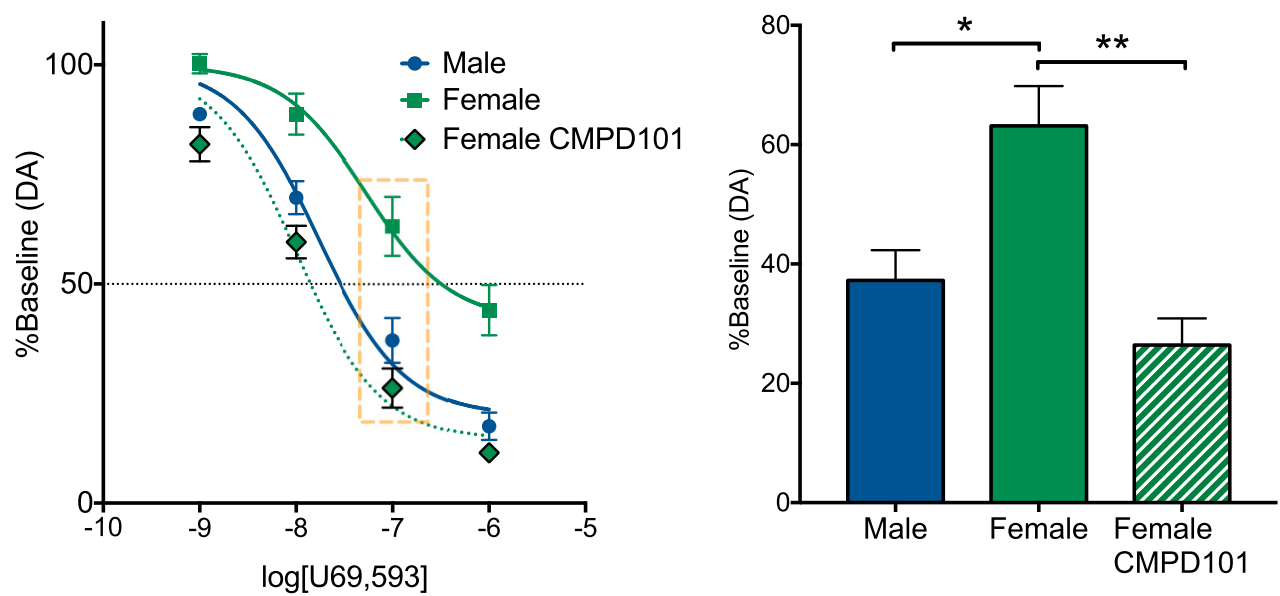

Figure 4. GRK2 sequesters $\mathrm{G} \beta \gamma$ to decrease KOR-mediated ERK phosphorylation and dopamine release inhibition in females. $A$, Striatal mRNA from male and female mice was isolated and analyzed for GRK2 expression. No difference in GRK2 expression was observed ( $n=8$ per group). $\boldsymbol{B}$, Striatal protein from male and female mice was isolated and analyzed for GRK2 phosphorylation at Ser670 by Western blot. Phosphorylation of Ser670 was significantly elevated in female mice compared with male mice $(p<0.05, n=11-13)$. C, GRK2 was immunoprecipitated from striatal homogenates of ovariectomized female mice treated with vehicle or estradiol ( $50 \mu \mathrm{g} / \mathrm{kg} ; 60 \mathrm{~min}$ before tissue collection). Samples were then immunoblotted for GRK2 and G $\beta$. No differences were observed in $\mathrm{G} \beta$ in total protein, but estradiol increased $\mathrm{G} \beta$ in GRK2 immunoprecipitates $(p<0.005, n=8-10)$. D, Female mice were treated with CMPD101 (1.25 mg/kg) $30 \mathrm{~min}$ before U50488 $(10 \mathrm{mg} / \mathrm{kg}, 15 \mathrm{~min})$. Striatal proteins were isolated and analyzed for ERK1/2 phosphorylation $(n=3-4)$. CMPD101 pretreatment significantly $(p<0.01)$ elevated ERK1/2 phosphorylation following U50488. $\boldsymbol{E}$, Concentration-response curves for U50488 inhibition of evoked dopamine release were determined using fast scan cyclic voltammetry in slices ( $n=5-9$ per group) from male and female mice. Nonlinear regression showed that KOR-mediated dopamine inhibition was significantly different between control and CMPD101-treated females. $F$, Dopamine release inhibition at the $100 \mathrm{~nm}$ dose of U50488 from $\boldsymbol{E}$ was examined. U50488 at $100 \mathrm{~nm}$ produced significantly less inhibition of dopamine release in slices from females than from males or females in the presence of $30 \mu \mathrm{M}$ CMPD101. Error bars indicate SEM. ${ }^{*} p<0.05,{ }^{* *} p<0.01$. 
effect was observed in spinal cord $(n=3-5)$, with an increase in GRK2 association with $G \beta \gamma$ in the immunoprecipitate following estradiol treatment (142 $\pm 19 \%$ of average expression) compared with the input sample treated with estradiol (104 $\pm 19 \%$ of average expression), suggesting that GRK2 modulates KOR signaling in the spinal cord as well.

G $\beta \gamma$ regulates ERK phosphorylation via PI3K $\gamma$ and Ras activity (Lopez-Ilasaca et al., 1997; Belcheva et al., 1998) and we hypothesized that inhibition of GRK2 would reveal, G proteinmediated effects of KOR activation in females. We first tested whether the selective GRK2/3 inhibitor CMPD101 (Thal et al., 2011; Lowe et al., 2015) (1.25 mg/kg; Tocris Bioscience) could unmask KOR-mediated ERK phosphorylation in females (Fig. $4 D)$. There was a significant effect of $\operatorname{sex}\left(F_{(1,11)}=8.64, p=\right.$ $0.014)$ and an interaction between sex and drug treatment $\left(F_{(1,11)}=8.64, p=0.0135\right)$. KOR activation in females treated 30 min after CMPD101 significantly increased ERK phosphorylation $(p=0.002)$ compared with females pretreated with saline. These results suggested that KOR/G $\beta \gamma$-mediated intracellular signaling effects in the striatum were evident in females following GRK2/3 inhibition.

We next tested whether presynaptic inhibition of transmitter release by KOR activation (Chefer et al., 2005) was different in males and females using dopamine voltammetry in the striatum. Concentration-response curves were generated for the KOR agonist U69593 as described previously (Ehrich et al., 2015). Treatment with U69593 inhibited evoked dopamine release with an $\mathrm{EC}_{50}$ of $17 \mathrm{~nm}$ (95\% CI: 11-27 nM) males and $63 \mathrm{~nm}$ (95\% CI: 27-148 nM) in females. U69593 was significantly more potent in males than females across multiple doses (nonlinear regression, $F_{(4,81)}=12.9, p<0.0001$ ) (Fig. $4 E, F$ ). There was a significant difference $\left(F_{(2,19)}=5.199, p=0.0158\right)$ in the $\log \mathrm{EC}_{50}$ between groups and post hoc analysis showed that there was a nonsignificant trend $(p=0.087)$ toward a difference between males and females. Slices prepared from females incubated with $30 \mu \mathrm{M}$ CMPD101 showed a significantly $(p=0.0013)$ lower U69593 $\log \mathrm{EC}_{50}\left(\mathrm{EC}_{50}: 10 \mathrm{~nm}\right.$; 95\% CI: 6-16 nM) compared with female slices in the absence of CMPD101. There was no effect of CMPD101 treatment alone on dopamine release. To further assess dose effects of CMPD101, we examined a U69593 dose close to the $\mathrm{EC}_{50}$ of all three groups at a $100 \mathrm{~nm}$ concentration (Fig. $4 F$ ) and found that there was a significant effect of group $\left(F_{(2,19)}=\right.$ 9.69, $p=0.0013)$. Post hoc analysis confirmed the potency of U69593 was significantly lower in female brain slices than in either slices of male brain or slices of female brain in the presence of CPMD101 $(p=0.011)$. Together, these studies demonstrated that pharmacological inhibition of GRK2 in females could restore KOR-mediated ERK phosphorylation and dopamine release inhibition that was quantitatively similar to the effects produced in males.

\section{Pharmacological inhibition of GRK2/3 enhances opioid-mediated analgesia in females}

Our biochemical and voltammetric data showed that GRK2/3 inhibition with CMPD 101 enables G $\beta \gamma$-mediated KOR intracellular and neural circuit level signals in females, suggesting that KOR-mediated analgesia may also be regulated by estrogenmediated phosphorylation of GRK2. We tested whether GRK2/3 blockade would unmask KOR analgesia in the warm water tail flick assay. CMPD101 pretreatment did not significantly alter baseline analgesic response; however, KOR activation in CMPD101 pretreated females produced a significant increase in tail flick latency $\left(F_{(1,12.5)}=31.7, p<0.0001\right.$; post hoc: $\left.p=0.0003\right)$. To assess the specificity of CMPD101, which inhibits both GRK2 and GRK3, we determined the necessity of GRK3 for the effects of CMPD101 on KOR-mediated analgesia and there was a significant difference between groups $\left(F_{(2,45)}=6.31, p=0.004\right)$. U50488 in GRK3 knock-outs and littermate controls did not produce a significant analgesic response, but U50488 did increase tail withdrawal latency in female GRK3 knock-out mice pretreated with CMPD101. The response in the presence of CMPD101 was significantly different from WT controls $(p=0.013)$ and GRK3 knock-out mice $(p=0.007)$.

Based on our observations with KOR responses in females, we predicted that analgesic responses to MOR activation with morphine may also be attenuated by GRK2 activity in females. There was a significant interaction between drug treatment and sex $\left(F_{(1,27)}=5.21, p=0.031\right)$ and post hoc analyses showed that females pretreated with saline showed a significantly different response to morphine compared with females pretreated with CMPD101 $(p=0.022)$. We observed that blockade of GRK2 enhances KOR- and MOR-mediated analgesic responses in females. These studies demonstrate that estradiol stimulates GRK2 phosphorylation to increase $G \beta \gamma$ sequestration and block $G$ protein-mediated biochemical, circuit, and behavioral effects of opioid receptor activation (for schematic, see Fig. 5D).

\section{Discussion}

These studies demonstrate that females show blunted intracellular, neural circuit, and behavioral responses to the $G$ proteinmediated actions of KOR agonists. In particular, elevated estradiol was found to underlie the reduction in KOR function in females. Furthermore, we specifically identified estradiol upregulation of GRK2 activity to mediate the observed sex differences in opioid analgesic responses. GRK2-dependent blunting of the analgesic effects of MOR agonist-induced analgesia was also observed in females, suggesting that estradiol-stimulated GRK2 may regulate other GPCR systems.

\section{Sex differences in KOR function}

Whereas the $G$ protein-mediated analgesic effects were subject to estradiol regulation, dysphoric effects of KOR activation were observed in both male and female mice. Although there are cycleindependent effects of KOR activation on aspects of rewardseeking behaviors in females (Russell et al., 2014), we did not observe significant sex effects on conditioned place aversion. These aversive effects are mediated by activation of the p38 MAPK (Bruchas et al., 2007b; Land et al., 2009; Bruchas et al., 2011; Ehrich et al., 2015, Schindler et al., 2012) and we found that p38 MAPK phosphorylation was increased in both B6 males and females following KOR activation. In contrast, G proteinmediated molecular or cellular effects, including ERK1/2 phosphorylation (Belcheva et al., 2005) and dopamine release inhibition (Ehrich et al., 2015), were blunted following KOR activation. The attenuation of $\mathrm{G}$ protein-mediated signals through estradiol/GRK2 regulation also decreased analgesic behavioral responses in $\mathrm{B} 6$ females following KOR activation. An alternative explanation for sex differences in KOR activation is that there are sex-dependent regional differences in kinase recruitment (Liu et al., 2018); however, this hypothesis cannot account for the CMPD101-sensitive differences in KOR-mediated ERK1/2 activation or inhibition of dopamine release.

Few selective KOR agonists have been tested for sex differences in analgesic efficacy in humans (Coffin et al., 1996, Delvaux et al., 1999), but nonselective MOR/KOR agonists have been reported to produce greater analgesia in women than in men (Gear 
A

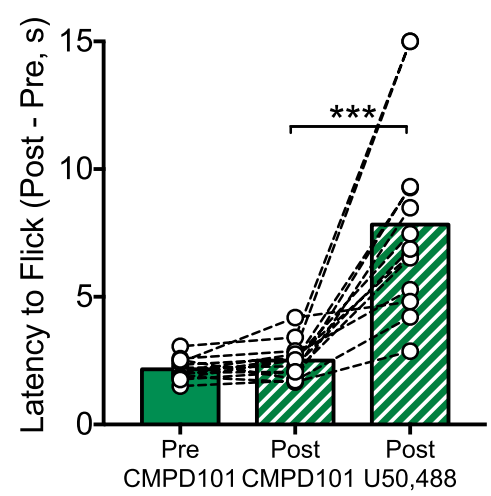

C

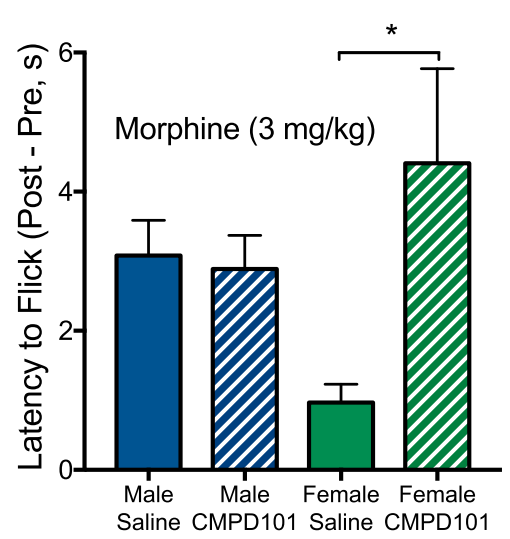

B
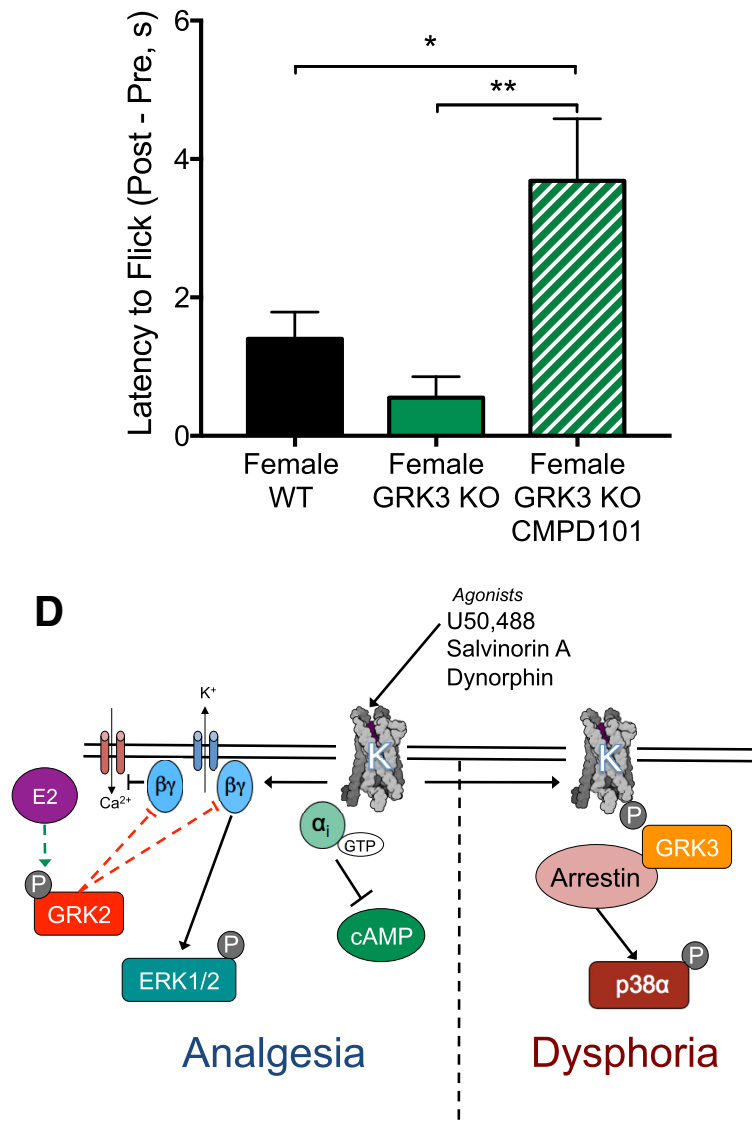

Figure 5. Pharmacological inhibition of GRK2/3 enhances opioid-mediated analgesia in females. $A$, Pretreatment with CMPD101 did not alter baseline tail flick latency in females ( $n=13)$. CMPD101 pretreatment significantly increased latency to flick with U50488 treatment in females $(p<0.001)$. B, Female WT data are replotted from Figure $1 C$. Female Grk3 ${ }^{-1-}$ mice $(n=9-14$ per group) pretreated with CMPD101 showed a significant increase in latency to flick compared with WT females $(p<0.05)$ or Grk3 ${ }^{-1-}(p<0.01)$ pretreated with saline. C, Submaximal dose $(3$ $\mathrm{mg} / \mathrm{kg}$ ) of morphine produces analgesia in males ( $n=7-8$ per group), with no effect of CMPD101, but the analgesic effect of morphine is blunted in females pretreated with saline ( $n=8$ per group) compared with females pretreated with CMPD101 $(p<0.05)$. D, In the proposed model, elevated estradiol (E2) in female mice results in GRK2 phosphorylation and enhanced sequestration of the $\mathrm{G} \beta \gamma$ subunits. This results in reduced $\mathrm{G} \beta \gamma$ signaling, including a reduction in analgesic responses. In contrast, GRK3/arrestin-mediated signaling is left largely intact, maintaining the aversive response. Error bars indicate SEM. ${ }^{*} p<0.05,{ }^{* *} p<0.01,{ }^{* * *} p<0.001$.

et al., 1996). The discrepancy between rodent and human studies may be due to innate signaling differences in KOR function between rodents and humans (Schattauer et al., 2012; Broad et al., 2016) or to synergistic interactions between MOR/KOR. In female rats, increased MOR/KOR heterodimerization in the spinal cord during periods of high estrogen or progesterone is associated with increased analgesic responses to intrathecal morphine administration (Chakrabarti et al., 2010; Liu et al., 2011, 2017). In addition to species differences, there may be differences in spinal and supraspinal KOR responses (Lawson et al., 2010) that produce inconsistencies in KOR-mediated analgesia. Reviews of the literature describing analgesic effects of selective KOR agonists in rodents concluded that there were mixed effects of KOR agonists in females (Craft, 2003; Fillingim and Gear, 2004; Rasakham and Liu-Chen, 2011), but the mechanisms underlying this variability were previously unknown.

\section{Estradiol blunts KOR-mediated analgesia}

Mogil et al. (2003) showed that ovariectomy restored KORmediated analgesia and this effect was blocked by estradiol replacement. In agreement with Mogil et al. (2003), our results show that estradiol blunts KOR-mediated analgesia and suggests that reported inconsistencies in KOR-mediated analgesia in females may be due to differences in estrogen levels between study subjects. Progesterone may also alter KOR function in female rats because systemic progesterone administration in gonadectomized or progesterone receptor antagonism alters analgesic responses to U50488 (Stoffel et al., 2005; Liu et al., 2011). Changes in either or both of these hormones may underlie the analgesic effects we observed in pregnant female mice. The multiple sites of action underlying sex differences in KOR analgesia (Mogil et al., 2003; Chakrabarti et al., 2010) indicates that there are complex interactions among agonist dose, administration route, rodent species, and behavioral assays for pain that could be explored in future studies to determine optimal treatment strategies in humans.

Estradiol can produce complex effects on mood and behavior through estrogen receptor activation or interactions with GPCR signaling (Gillies and MacArthur, 2010; Martinez et al., 2016). Based on the observation that KOR activation did not produce analgesia or ERK phosphorylation, we hypothesized that an estradiol-regulated signaling system that controls $G$ proteinbiased signals was likely to be a mechanistic target for sexually dimorphic responses. GRK2 is phosphorylated following estra- 
diol treatment, likely through estrogen receptor $\alpha$ (Dominguez et al., 2009), sequesters $G_{\beta \gamma}$ subunits (Lodowski et al., 2003), and decreases ERK activation (Pitcher et al., 1999). GRK2 activity also desensitizes KOR activity in cardiac tissue (Chen et al., 2017), suggesting that estradiol modulation of GRK2 activity could underlie sex differences in KOR activity. Our results showed that, in females, GRK2 phosphorylation was increased and there was no change in GRK2 mRNA levels. We also observed increased association of GRK2 with $\mathrm{G}_{\beta \gamma}$ subunits following estradiol treatment in ovariectomized females, indicating that estradiol increased GRK2 sequestration of $G_{\beta \gamma}$ to blunt $G$ protein-mediated signals.

\section{GRK2 regulates opioid analgesia in females}

We found that pharmacological inhibition of GRK2 with CMPD101 attenuated sex differences following KOR activation. CMPD101 is a selective inhibitor for members of the GRK2 subfamily (GRK2 and GRK3), with little activity at GRK1 or GRK5 (Thal et al., 2011). To ensure that the effects that we observed were selective to GRK2, we tested the effect of CMPD101 in female Grk $3^{-1-}$ mice and found that the CMPD101-mediated increase in KOR analgesia was not GRK3 dependent. Global genetic deletion of GRK2 in mice causes death during embryonic development (Jaber et al., 1996), preventing an assessment of CMPD101 in GRK2 knock-out mice. In addition to sequestration of $\mathrm{G}_{\beta \gamma}$, GRK2 can also interact with MEK to inhibit phosphorylation of ERK, suggesting an additional level of regulation over GPCR signaling that may contribute to our observed GRK2mediated effects. GRK2 has also been shown to desensitize melanocortin-1 receptor (Sánchez-Más et al., 2005), which may contribute to sex-dependent analgesic effects of KOR agonists (Mogil et al., 2003). Together, these studies showed that GRK2 inhibition is sufficient to decrease KOR-mediated sex differences at a biochemical, neural circuit, and behavioral level in mice.

Whereas $G$ protein-mediated analgesic effects were decreased, anti-pruritic effects of KOR activation remained evident in females. Although nalfurafine is a G-biased KOR compound (Schattauer et al., 2017), our results suggest that not all G proteinmediated effects may be subject to GRK2 regulation. For example, KOR activation can also disrupt cognition through G protein-mediated actions, but cognitive disruptions following KOR activation are not sexually dimorphic (Abraham et al., 2018). These findings suggest that there are some KOR/G protein-mediated behaviors that may not be regulated by GRK2 or may not require G $\beta \gamma$ activity. GRK2 interacts with $G \beta 1$ and $\mathrm{G} \beta 2$, but not $\mathrm{G} \beta 3$ (Belcheva et al., 1998), indicating that there may be differential regulation of $\mathrm{G} \beta$-mediated behaviors depending on the $G \beta$ subunits or cell populations required for behavioral effects. Additionally, anti-pruritic and cognitive effects may be regulated by inhibitory interactions between $\mathrm{G} \alpha$ i and downstream effectors such as Ras, JNK, or protein kinase A (Edamatsu et al., 1998; Dessauer et al., 2002; Pierre et al., 2009). Munanairi et al. (2018) reported that KOR-mediated decreases in itch are sex independent and may not require $\mathrm{G}$ protein activation, instead using phospholipase $\mathrm{C}$, supporting our observation of the anti-pruritic effects of KOR activation in males and females. The reported actions of KOR on diuresis (Leander, 1983; Craft et al., 2000) and locomotor activity (Robles et al., 2014) are also not sex dependent, suggesting that these behaviors are likely regulated by cellular and molecular mechanisms that are distinct from KOR-mediated analgesia. Additionally, KOR antagonists have also been reported to differ in efficacy between males and females (Laman-Maharg et al., 2018). To increase the efficacy and specificity of KOR agonists and antagonists, future studies could aim to dissociate the molecular signals or cellular populations producing analgesia from those producing diuretic, antipruritic, sedative, and cognitive effects of KOR activation.

Similar to the analgesic effects observed with KOR, blockade of GRK2 also promoted analgesic responses to morphine in females, a MOR-selective opiate (Goldstein and Naidu, 1989). GRK2 overexpression with MOR in cell culture increases activation of arrestin-dependent signals (Zhang et al., 1998), suggesting that GRK2 decreases MOR G protein-mediated signals, similar to GRK2-KOR interactions. Sex differences in morphine analgesia at low doses have been hypothesized to occur through regulation of $\mathrm{G}$ protein-coupled inwardly rectifying potassium channels (Mitrovic et al., 2003), which are also known to directly bind $\mathrm{G}_{\beta \gamma}$ for channel activation (Huang et al., 1995). Our studies demonstrated that sex differences in opioid receptor activity were the result of GRK2 activity and suggest that multiple inhibitory GPCRs could be subject to a similar sex-dependent regulation. Future studies could assess the role of GRK2 in decreasing G $\alpha \mathrm{i}$ protein-mediated behaviors in other GPCR systems.

Together, our studies demonstrate that KOR activation produces distinct analgesic effects in males and females in an estradiol- and GRK2-regulated manner. G protein-biased KOR analgesic compounds that are in clinical development may have sex-dependent effects and careful consideration of estradiol interactions with opioid receptor actions is required for the implementation of biased KOR agonists in clinical populations. Further understanding of the mechanisms underlying sexually dimorphic effects of opioid receptor activation could guide the development of highly efficacious nonaddictive opioid drugs for analgesia in males and females.

\section{References}

Abraham AD, Fontaine HM, Song AJ, Andrews MM, Baird MA, Kieffer BL, Land BB, Chavkin C (2018) Kappa opioid receptor activation in dopamine neurons disrupts behavioral inhibition. Neuropsychopharmacology 43:362-372. CrossRef Medline

Belcheva MM, Vogel Z, Ignatova E, Avidor-Reiss T, Zippel R, Levy R, Young EC, Barg J, Coscia CJ (1998) Opioid modulation of extracellular signalregulated protein kinase activity is ras-dependent and involves gbetagamma subunits. J Neurochem 70:635-645. Medline

Belcheva MM, Clark AL, Haas PD, Serna JS, Hahn JW, Kiss A, Coscia CJ (2005) $\mu$ and $\kappa$ opioid receptors activate ERK/MAPK via different protein kinase $\mathrm{C}$ isoforms and secondary messengers in astrocytes. J Biol Chem 280:27662-27669. CrossRef Medline

Berkley KJ (1997) Sex differences in pain. Behav Brain Sci 20:371-380; discussion 435-513. Medline

Broad J, Maurel D, Kung VW, Hicks GA, Schemann M, Barnes MR, Kenakin TP, Granier S, Sanger GJ (2016) Human native kappa opioid receptor functions not predicted by recombinant receptors: implications for drug design. Sci Rep 6:30797. CrossRef Medline

Bruchas MR, Chavkin C (2010) Kinase cascades and ligand-directed signaling at the kappa opioid receptor. Psychopharmacology (Berl) 210:137147. CrossRef Medline

Bruchas MR, Macey TA, Lowe JD, Chavkin C (2006) Kappa opioid receptor activation of 38 MAPK is GRK3- and arrestin-dependent in neurons and astrocytes. J Biol Chem 281:18081-18089. CrossRef Medline

Bruchas MR, Yang T, Schreiber S, Defino M, Kwan SC, Li S, Chavkin C (2007a) Long-acting kappa opioid antagonists disrupt receptor signaling and produce noncompetitive effects by activating c-jun N-terminal kinase. J Biol Chem 282:29803-29811. CrossRef Medline

Bruchas MR, Land BB, Aita M, Xu M, Barot SK, Li S, Chavkin C (2007b) Stress-induced p38 mitogen-activated protein kinase activation mediates kappa-opioid-dependent dysphoria. J Neurosci 27:11614-11623. CrossRef Medline

Bruchas MR, Schindler AG, Shankar H, Messinger DI, Miyatake M, Land BB, Lemos JC, Hagan CE, Neumaier JF, Quintana A, Palmiter RD, Chavkin C (2011) Selective p38 $\alpha$ MAPK deletion in serotonergic neurons produces 
stress resilience in models of depression and addiction. Neuron 71:498511. CrossRef Medline

Brust TF, Morgenweck J, Kim SA, Rose JH, Locke JL, Schmid CL, Zhou L, Stahl EL, Cameron MD, Scarry SM, Aubé J, Jones SR, Martin TJ, Bohn LM (2016) Biased agonists of the kappa opioid receptor suppress pain and itch without causing sedation or dysphoria. Sci Signal 9:ra117. CrossRef 27899527

Chakrabarti S, Liu NJ, Gintzler AR (2010) Formation of $\mu$-/ $\kappa$-opioid receptor heterodimer is sex-dependent and mediates female-specific opioid analgesia. Proc Natl Acad Sci U S A 107:20115-20119. CrossRef Medline

Chartoff EH, Mavrikaki M (2015) Sex differences in kappa opioid receptor function and their potential impact on addiction. Front Neurosci 9:466. CrossRef Medline

Chavkin C, Koob GF (2016) Dynorphin, dysphoria, and dependence: the stress of addiction. Neuropsychopharmacology 41:373-374. CrossRef Medline

Chefer VI, Czyzyk T, Bolan EA, Moron J, Pintar JE, Shippenberg TS (2005) Endogenous kappa-opioid receptor systems regulate mesoaccumbal dopamine dynamics and vulnerability to cocaine. J Neurosci 25:5029-5037. CrossRef Medline

Chen X, Zhao S, Xia Y, Xiong Z, Li Y, Tao L, Zhang F, Wang X (2017) G protein-coupled receptor kinase 2 upregulation causes kappa-opioid receptor desensitization in diabetic heart. Biochem Biophys Res Commun 482:658-664. CrossRef Medline

Clark JJ, Sandberg SG, Wanat MJ, Gan JO, Horne EA, Hart AS, Akers CA, Parker JG, Willuhn I, Martinez V, Evans SB, Stella N, Phillips PE (2010) Chronic microsensors for longitudinal, subsecond dopamine detection in behaving animals. Nat Methods 7:126-129. CrossRef Medline

Coffin B, Bouhassira D, Chollet R, Fraitag B, De Meynard C, Geneve J, Lemann M, Willer JC, Jian R (1996) Effect of the kappa agonist fedotozine on perception of gastric distension in healthy humans. Aliment Pharmacol Ther 10:919-925. CrossRef Medline

Craft RM (2003) Sex differences in opioid analgesia: from mouse to man. Clin J Pain 19:175-186. CrossRef Medline

Craft RM (2008) Sex differences in analgesic, reinforcing, discriminative, and motoric effects of opioids. Exp Clin Psychopharmacol 16:376-385. CrossRef Medline

Craft RM, Ulibarri CM, Raub DJ (2000) Kappa opioid-induced diuresis in female vs. male rats. Pharmacol Biochem Behav 65:53-59. CrossRef Medline

Daaka Y, Pitcher JA, Richardson M, Stoffel RH, Robishaw JD, Lefkowitz RJ (1997) Receptor and G $\beta \gamma$ isoform-specific interactions with G proteincoupled receptor kinases. Proc Natl Acad Sci U S A 94:2180-2185. CrossRef Medline

Delvaux M, Louvel D, Lagier E, Scherrer B, Abitbol JL, Frexinos J (1999) The kappa agonist fedotozine relieves hypersensitivity to colonic distention in patients with irritable bowel syndrome. Gastroenterology 116:38-45. CrossRef Medline

Delvaux M, Beck A, Jacob J, Bouzamondo H, Weber FT, Frexinos J (2004) Effect of asimadoline, a kappa opioid agonist, on pain induced by colonic distension in patients with irritable bowel syndrome. Aliment Pharmacol Ther 20:237-246. CrossRef Medline

Dessauer CW, Chen-Goodspeed M, Chen J (2002) Mechanism of G $\alpha \mathrm{i}^{-}$ mediated inhibition of type V adenylyl cyclase. J Biol Chem 277:2882328829. CrossRef Medline

Dominguez R, Hu E, Zhou M, Baudry M (2009) $17 \beta$-estradiol-mediated neuroprotection and ERK activation require a pertussis toxin-sensitive mechanism involving GRK2 and $\beta$-arrestin-1. J Neurosci 29:4228-4238. CrossRef Medline

Edamatsu H, Kaziro Y, Itoh H (1998) Expression of an oncogenic mutant G $\alpha$ i2 activates ras in rat-1 fibroblast cells. FEBS Lett 440:231-234. CrossRef Medline

Ehrich JM, Messinger DI, Knakal CR, Kuhar JR, Schattauer SS, Bruchas MR, Zweifel LS, Kieffer BL, Phillips PE, Chavkin C (2015) Kappa opioid receptor-induced aversion requires $\mathrm{p} 38$ MAPK activation in VTA dopamine neurons. J Neurosci 35:12917-12931. CrossRef Medline

Eisenach JC, Carpenter R, Curry R (2003) Analgesia from a peripherally active kappa-opioid receptor agonist in patients with chronic pancreatitis. Pain 101:89-95. CrossRef Medline

Fillingim RB, Gear RW (2004) Sex differences in opioid analgesia: clinical and experimental findings. Eur J Pain 8:413-425. CrossRef Medline

Gear RW, Miaskowski C, Gordon NC, Paul SM, Heller PH, Levine JD (1996)
Kappa-opioids produce significantly greater analgesia in women than in men. Nat Med 2:1248-1250. CrossRef Medline

Gillies GE, McArthur S (2010) Estrogen actions in the brain and the basis for differential action in men and women: a case for sex-specific medicines. Pharmacol Rev 62:155-198. CrossRef Medline

Goldstein A, Naidu A (1989) Multiple opioid receptors: ligand selectivity profiles and binding site signatures. Mol Pharmacol 36:265-272. Medline

Green R, Luttge WG, Whalen RE (1970) Induction of receptivity in ovariectomized female rats by a single intravenous injection of estradiol- $17 \beta$. Physiol Behav 5:137-141. CrossRef Medline

Huang CL, Slesinger PA, Casey PJ, Jan YN, Jan LY (1995) Evidence that direct binding of $\mathrm{G} \beta \gamma$ to the GIRK1 G protein-gated inwardly rectifying $\mathrm{K}+$ channel is important for channel activation. Neuron 15:1133-1143. CrossRef Medline

Inan S, Dun NJ, Cowan A (2011) Investigation of gastrin-releasing peptide as a mediator for $5^{\prime}$-guanidinonaltrindole-induced compulsive scratching in mice. Peptides 32:286-292. CrossRef Medline

Jaber M, Koch WJ, Rockman H, Smith B, Bond RA, Sulik KK, Ross J Jr, Lefkowitz RJ, Caron MG, Giros B (1996) Essential role of betaadrenergic receptor kinase 1 in cardiac development and function. Proc Natl Acad Sci U S A 93:12974-12979. CrossRef Medline

Laman-Maharg A, Williams AV, Zufelt MD, Minie VA, Ramos-Maciel S, Hao R, Ordoñes Sanchez E, Copeland T, Silverman JL, Leigh A, Snyder R, Carroll FI, Fennell TR, Trainor BC (2018) Sex differences in the effects of a kappa opioid receptor antagonist in the forced swim test. Front Pharmacol 9:93. CrossRef Medline

Land BB, Bruchas MR, Schattauer S, Giardino WJ, Aita M, Messinger D, Hnasko TS, Palmiter RD, Chavkin C (2009) Activation of the kappa opioid receptor in the dorsal raphe nucleus mediates the aversive effects of stress and reinstates drug seeking. Proc Natl Acad Sci U S A 106:1916819173. CrossRef Medline

Lawson KP, Nag S, Thompson AD, Mokha SS (2010) Sex-specificity and estrogen-dependence of kappa opioid receptor-mediated antinociception and antihyperalgesia. Pain 151:806-815. CrossRef Medline

Leander JD (1983) A kappa opioid effect: increased urination in the rat. J Pharmacol Exp Ther 224:89-94. Medline

Lemos JC, Wanat MJ, Smith JS, Reyes BA, Hollon NG, Van Bockstaele EJ, Chavkin C, Phillips PE (2012) Severe stress switches CRF action in the nucleus accumbens from appetitive to aversive. Nature 490:402-406. CrossRef Medline

Liu JJ, Sharma K, Zangrandi L, Chen C, Humphrey SJ, Chiu YT, Spetea M, Liu-Chen LY, Schwarzer C, Mann M (2018) In vivo brain GPCR signaling elucidated by phosphoproteomics. Science 360:eaao4927. CrossRef Medline

Liu NJ, Chakrabarti S, Schnell S, Wessendorf M, Gintzler AR (2011) Spinal synthesis of estrogen and concomitant signaling by membrane estrogen receptors regulate spinal $\kappa$ - and $\mu$-opioid receptor heterodimerization and female-specific spinal morphine antinociception. J Neurosci 31: 11836-11845. CrossRef Medline

Liu NJ, Murugaiyan V, Storman EM, Schnell SA, Kumar A, Wessendorf MW, Gintzler AR (2017) Plasticity of signaling by spinal estrogen receptor $\alpha$, $\kappa$-opioid receptor, and metabotropic glutamate receptors over the rat reproductive cycle regulates spinal endomorphin 2 antinociception: relevance of endogenous-biased agonism. J Neurosci 37:11181-11191. CrossRef Medline

Lodowski DT, Pitcher JA, Capel WD, Lefkowitz RJ, Tesmer JJ (2003) Keeping $\mathrm{G}$ proteins at bay: a complex between $\mathrm{G}$ protein-coupled receptor kinase 2 and G $\beta \gamma$. Science 300:1256-1262. CrossRef Medline

Lopez-Ilasaca M, Crespo P, Pellici PG, Gutkind JS, Wetzker R (1997) Linkage of $\mathrm{G}$ protein-coupled receptors to the MAPK signaling pathway through PI3-kinase $\gamma$. Science 275:394-397. CrossRef Medline

Lowe JD, Sanderson HS, Cooke AE, Ostovar M, Tsisanova E, Withey SL, Chavkin C, Husbands SM, Kelly E, Henderson G, Bailey CP (2015) Role of $\mathrm{G}$ protein-coupled receptor kinases 2 and 3 in $\mu$-opioid receptor desensitization and internalization. Mol Pharmacol 88:347-356. CrossRef Medline

Martinez LA, Gross KS, Himmler BT, Emmitt NL, Peterson BM, Zlebnik NE, Foster Olive M, Carroll ME, Meisel RL, Mermelstein PG (2016) Estradiol facilitation of cocaine self-administration in female rats requires activation of mGluR5. eNeuro 3:ENEURO.0140-16.2016. CrossRef Medline

McCormack JT, Greenwald GS (1974) Progesterone and oestradiol-17beta 
concentrations in the peripheral plasma during pregnancy in the mouse. J Endocrinol 62:101-107. CrossRef Medline

McLaughlin JP, Marton-Popovici M, Chavkin C (2003) Kappa opioid receptor antagonism and prodynorphin gene disruption block stressinduced behavioral responses. J Neurosci 23:5674-5683. CrossRef Medline

McLaughlin JP, Myers LC, Zarek PE, Caron MG, Lefkowitz RJ, Czyzyk TA, Pintar JE, Chavkin C (2004) Prolonged kappa opioid receptor phosphorylation mediated by $\mathrm{G}$ protein receptor kinase underlies sustained analgesic tolerance. J Biol Chem 279:1810-1818. CrossRef Medline

McLean AC, Valenzuela N, Fai S, Bennett SA (2012) Performing vaginal lavage, crystal violet staining, and vaginal cytological evaluation for mouse estrous cycle staging identification. J Vis Exp 67:e4389. CrossRef Medline

Mitrovic I, Margeta-Mitrovic M, Bader S, Stoffel M, Jan LY, Basbaum AI (2003) Contribution of GIRK2-mediated postsynaptic signaling to opiate and alpha 2 -adrenergic analgesia and analgesic sex differences. Proc Natl Acad Sci U S A 100:271-276. CrossRef Medline

Mogil JS, Wilson SG, Chesler EJ, Rankin AL, Nemmani KV, Lariviere WR, Groce MK, Wallace MR, Kaplan L, Staud R, Ness TJ, Glover TL, Stankova M, Mayorov A, Hruby VJ, Grisel JE, Fillingim RB (2003) The melanocortin-1 receptor gene mediates female-specific mechanisms of analgesia in mice and humans. Proc Natl Acad Sci U S A 100:4867-4872. CrossRef Medline

Munanairi A, Liu XY, Barry DM, Yang Q, Yin JB, Jin H, Li H, Meng QT, Peng JH, Wu ZY, Yin J, Zhou XY, Wan L, Mo P, Kim S, Huo FQ, Jeffry J, Li YQ, Bardoni R, Bruchas MR, Chen ZF (2018) Non-canonical opioid signaling inhibits itch transmission in the spinal cord of mice. Cell Rep 23:866877. CrossRef Medline

Peppel K, Boekhoff I, McDonald P, Breer H, Caron MG, Lefkowitz RJ (1997) G protein-coupled receptor kinase 3 (GRK3) gene disruption leads to loss of odorant receptor desensitization. J Biol Chem 272:25425-25428. CrossRef Medline

Pfeiffer A, Brantl V, Herz A, Emrich HM (1986) Psychotomimesis mediated by kappa opiate receptors. Science 233:774-776. CrossRef Medline

Pierre S, Eschenhagen T, Geisslinger G, Scholich K (2009) Capturing adenylyl cyclases as potential drug targets. Nat Rev Drug Discov 8:321-335. CrossRef Medline

Pitcher JA, Tesmer JJ, Freeman JL, Capel WD, Stone WC, Lefkowitz RJ (1999) Feedback inhibition of G protein-coupled receptor kinase 2 (GRK2) activity by extracellular signal-regulated kinases. J Biol Chem 274:34531-34534. CrossRef Medline

Rasakham K, Liu-Chen LY (2011) Sex differences in kappa opioid pharmacology. Life Sci 88:2-16. CrossRef Medline

Raveh A, Cooper A, Guy-David L, Reuveny E (2010) Nonenzymatic rapid control of GIRK channel function by a $\mathrm{G}$ protein-coupled receptor kinase. Cell 143:750-760. CrossRef Medline

Robles CF, McMackin MZ, Campi KL, Doig IE, Takahashi EY, Pride MC, Trainor BC (2014) Effects of kappa opioid receptors on conditioned place aversion and social interaction in males and females. Behav Brain Res 262:84-93. CrossRef Medline

Russell SE, Rachlin AB, Smith KL, Muschamp J, Berry L, Zhao Z, Chartoff EH
(2014) Sex differences in sensitivity to the depressive-like effects of the kappa opioid receptor agonist U-50488 in rats. Biol Psychiatry 76:213222. CrossRef Medline

Russo SJ, Jenab S, Fabian SJ, Festa ED, Kemen LM, Quinones-Jenab V (2003) Sex differences in the conditioned rewarding effects of cocaine. Brain Res 970:214-220. CrossRef Medline

Sánchez-Más J, Guillo LA, Zanna P, Jiménez-Cervantes C, García-Borrón JC (2005) Role of G protein-coupled receptor kinases in the homologous desensitization of the human and mouse melanocortin 1 receptors. Mol Endocrinol 19:1035-1048. CrossRef Medline

Schattauer SS, Miyatake M, Shankar H, Zietz C, Levin JR, Liu-Chen LY, Gurevich VV, Rieder MJ, Chavkin C (2012) Ligand directed signaling differences between rodent and human $\kappa$-opioid receptors. J Biol Chem 287:41595-41607. CrossRef Medline

Schattauer SS, Kuhar JR, Song A, Chavkin C (2017) Nalfurafine is a G protein biased agonist having significantly greater bias at the human than rodent form of the kappa opioid receptor. Cell Signal 32:59-65. CrossRef Medline

Schindler AG, Messinger DI, Smith JS, Shankar H, Gustin RM, Schattauer SS, Lemos JC, Chavkin NW, Hagan CE, Neumaier JF, Chavkin C (2012) Stress produces aversion and potentiates cocaine reward by releasing endogenous dynorphins in the ventral striatum to locally stimulate serotonin reuptake. J Neurosci 32:17582-17596. CrossRef Medline

Sharifi N, Diehl N, Yaswen L, Brennan MB, Hochgeschwender U (2001) Generation of dynorphin knock-out mice. Brain Res Mol Brain Res 86: 70-75. CrossRef Medline

Shippenberg TS, Herz A (1986) Differential effects of mu and kappa opioid systems on motivational processes. NIDA Res Monogr 75:563-566. Medline

Smith JT, Cunningham MJ, Rissman EF, Clifton DK, Steiner RA (2005) Regulation of Kiss 1 gene expression in the brain of the female mouse. Endocrinology 146:3686-3692. CrossRef Medline

Stoffel EC, Ulibarri CM, Folk JE, Rice KC, Craft RM (2005) Gonadal hormone modulation of mu, kappa, and delta opioid antinociception in male and female rats. J Pain 6:261-274. CrossRef Medline

Terman GW, Jin W, Cheong YP, Lowe J, Caron MG, Lefkowitz RJ, Chavkin C (2004) G protein receptor kinase 3 (GRK3) influences opioid analgesic tolerance but not opioid withdrawal. Br J Pharmacol 141:55-64. CrossRef Medline

Thal DM, Yeow RY, Schoenau C, Huber J, Tesmer JJ (2011) Molecular mechanism of selectivity among $G$ protein-coupled receptor kinase 2 inhibitors. Mol Pharmacol 80:294-303. CrossRef Medline

Volkow ND, Collins FS (2017) The role of science in addressing the opioid crisis. N Engl J Med 377:391-394. CrossRef Medline

Von Voigtlander PF, Lewis RA (1982) U-50,488, a selective kappa opioid agonist: comparison to other reputed kappa agonists. Prog Neuropsychopharmacol Biol Psychiatry 6:467-470. CrossRef Medline

Zhang J, Ferguson SS, Barak LS, Bodduluri SR, Laporte SA, Law PY, Caron MG (1998) Role for G protein-coupled receptor kinase in agonistspecific regulation of $\mu$-opioid receptor responsiveness. Proc Natl Acad Sci U S A 95:7157-7162. CrossRef Medline 